\title{
MONITORING REGIONAL GROUND-WATER QUALITY-- STATISTICAL CONSIDERATIONS AND DESCRIPTION OF A MONITORING NETWORK IN KANSAS
}

By Timothy B. Spruill

\section{U.S. GEOLOGICAL SURVEY}

Water-Resources Investigations Report 90-4159

Prepared in cooperation with the

KANSAS DEPARTMENT OF HEALTH AND ENVIRONMENT

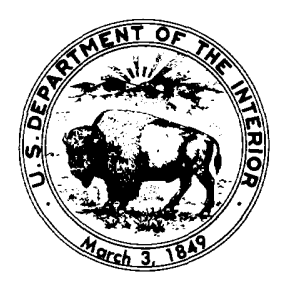

Lawrence, Kansas

1990 


\section{DEPARTMENT OF THE INTERIOR \\ MANUEL LUJAN, JR., Secretary \\ U.S. GEOLOGICAL SURVEY \\ Dallas L. Peck}

For additional information write to:

District Chief

U.S. Geological Survey

Water Resources Division

4821 Quail Crest Place

Lawrence, Kansas 66049
Copies of this report can be purchased from:

U.S. Geological Survey

Books and Open-File Reports

Denver Federal Center

Box 25425, Building 810

Denver, Colorado 80225 


\section{CONTENTS}

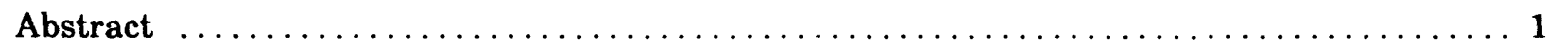

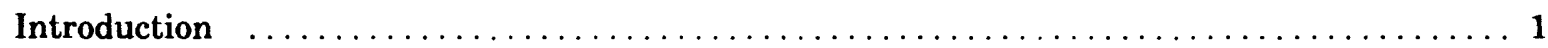

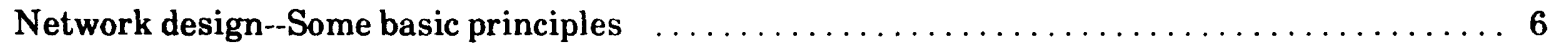

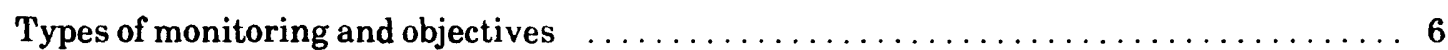



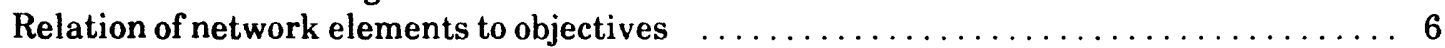

Statistical considerations in regional network design $\ldots \ldots \ldots \ldots \ldots \ldots \ldots \ldots \ldots$

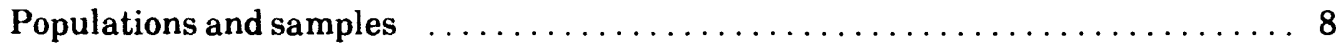

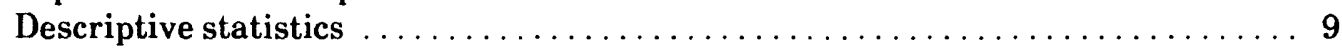

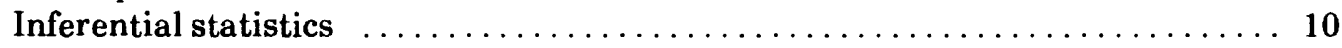

Network elements--Statistical aspects $\ldots \ldots \ldots \ldots \ldots \ldots \ldots \ldots \ldots \ldots \ldots \ldots \ldots$

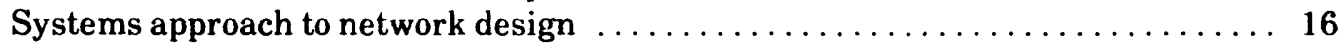



Description of Kansas ground-water-quality monitoring network--An example $\ldots \ldots \ldots \ldots 17$

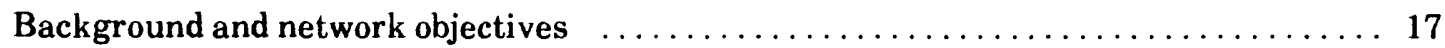

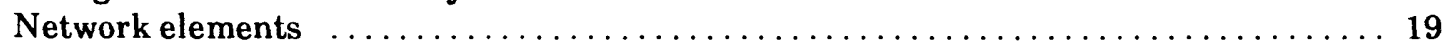

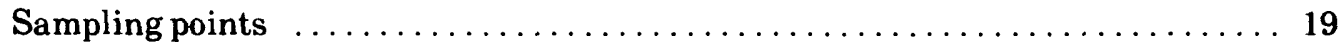

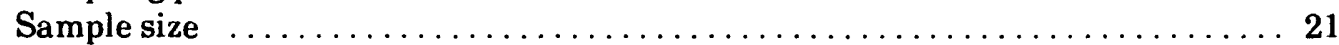

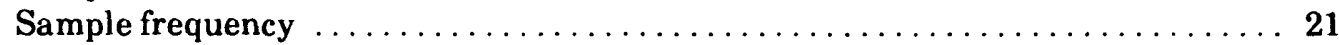

Sample collection and analysis procedures $\ldots \ldots \ldots \ldots \ldots \ldots \ldots \ldots \ldots \ldots \ldots$

Chemical constituents and properties to be monitored $\ldots \ldots \ldots \ldots \ldots \ldots 22$

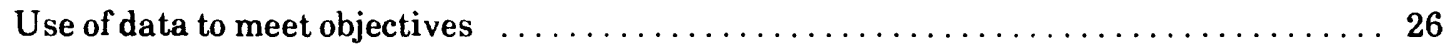

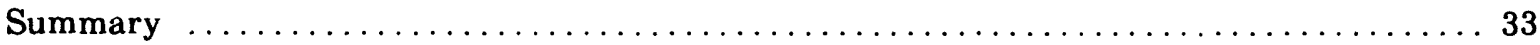

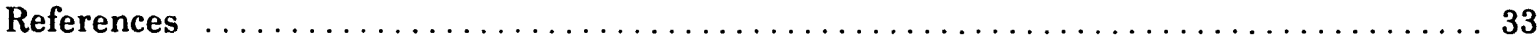

$\begin{array}{ll}\text { Appendices } & \text { Page }\end{array}$



II.--Computation of sample size for known distributions $\ldots \ldots \ldots \ldots \ldots \ldots \ldots \ldots$

III.--Computation of sample size for unknown distributions $\ldots \ldots \ldots \ldots \ldots \ldots \ldots . \ldots \ldots$

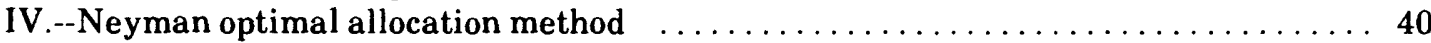




\section{CONTENTS--Continued}

Figure $\quad$ Page

1. Schematic representation of point, local, and regional monitoring $\ldots \ldots \ldots \ldots \ldots$

2. Graph showing location of mean, median, and 20th, 50th, and 80th percentiles in a

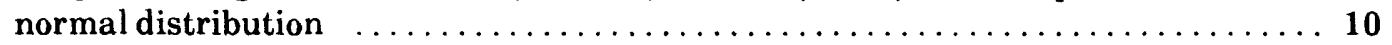

3. Graphs showing shapes of selected frequency distributions $\ldots \ldots \ldots \ldots \ldots \ldots \ldots 11$

4. Graphs showing examples of normal and positively skewed frequency distributions and relative location of mean and median values $\ldots \ldots \ldots \ldots \ldots \ldots \ldots \ldots \ldots$

5. Graph showing probability function of $\mathrm{X}$ for actual and assumed sample distributions 12

6. Graphs showing examples of sample estimate of population median and true



7. Map showing location of wells in Kansas ground-water-quality monitoring network,



8. Map showing ground-water regions of Kansas $\ldots \ldots \ldots \ldots \ldots \ldots \ldots \ldots \ldots$

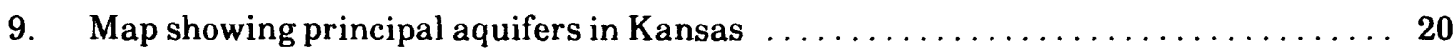

10. Map showing distribution of wells in Kansas ground-water-quality monitoring network sampled during 1988 water year $\ldots \ldots \ldots \ldots \ldots \ldots \ldots \ldots \ldots \ldots \ldots \ldots \ldots \ldots \ldots$

11. Maps showing median dissolved nitrate-nitrogen concentrations in Kansas groundwater supplies, 1976-81, and percentage of concentrations exceeding Maximum Contaminant Level of 10 milligrams per liter $\ldots \ldots \ldots \ldots \ldots \ldots \ldots \ldots \ldots$

12. Graph showing results of Spearman-rho analysis of trends in nitrate concentrations in water from Kansas network wells developed in glacial-drift aquifers in ground-water



1. Drinking-water standards established by the State of Kansas and the U.S.

Environmental Protection Agency for selected chemical constituents and compounds

2. Sample sizes for principal aquifers selected for sampling in ground-water regions of

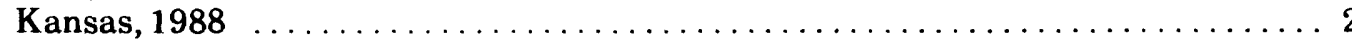

3. Quality-control information on laboratory analytical techniques for chemical constituents sampled in the Kansas ground-water-quality monitoring network ........ 


\section{CON'TENTS--Continued}

4. Sampling size, median, and 95-percent confidence intervals for median dissolved concentrations of nitrate as nitrogen, sulfate, and selenium in ground-water supplies in Kansas, 1976-81 ......................................... 27

5. Ninety-five percent confidence intervals for percentages of supply wells with water having dissolved concentrations exceeding drinking-water standards for nitrate as nitrogen, sulfate, and selenium in ground-water supplies in Kansas, 1976-81 . . . .

6. Dissolved nitrate-nitrogen concentrations in Kansas ground-water supplies, 1976-81 30

7. Sequence of numbers showing location of statistical values for 95-percent confidence interval of median

8. Allocation of samples in individual strata for describing dissolved-solids concentrations in 14 ground-water regions of Kansas 


\section{CONVERSION FACTORS}

For those interested readers, the inch-pound units used for the most part in this report can be converted to metric units (International System) using the following conversion factors:

\section{Multiply inch-pound unit}

foot

mile

square mile

acre

gallon

gallon per minute (gal/min)

degree Fahrenheit $\left({ }^{\circ} \mathrm{F}\right)$

${ }^{1 \circ} \mathrm{C}=5 / 9 \times\left({ }^{\circ} \mathrm{F}-32\right)$.
By

0.3048

1.609

2.590

4,047

3.785

0.06309

(1)
To obtain metric unit

meter

kilometer

square kilometer

square meter

liter

liter per second

degree Celsius $\left({ }^{\circ} \mathrm{C}\right)$ 


\title{
MONITORING REGIONAL GROUND-WATER QUALITY--STATISTICAL CONSIDERATIONS AND DESCRIPTION OF A MONITORING NETWORK IN KANSAS
}

\author{
By Timothy B. Spruill
}

\begin{abstract}
Ground-water-quality monitoring networks should be able to answer three general questions: (1) What is typical water quality? (2) Does the ground water that is available meet existing water-quality standards? (3) Are there indications that water quality is changing so that it will not meet standards in the future? Groundwater-quality monitoring networks can provide answers to these questions if they are carefully designed. This report presents basic statistical principles that can be used to design and evaluate data from a regional monitoring network and demonstrates use of these principles through an example of a groundwater-quality monitoring network in Kansas.
\end{abstract}

A monitoring network can be conceptualized as consisting of five basic elements: (1) sample points, (2) sample size, (3) sample frequency, (4) water-sample collection and analysis procedures, and (5) chemical constituents and properties to be monitored. The specific purpose of a monitoring objective determines how these network elements need to be implemented. Data derived from wells in a monitoring network (the sample) form a basis for making inferences about the population of interest. The population can be quality characteristics of water from an aquifer or, more commonly, quality characteristics of water from water-supply or monitoring wells in a particular aquifer. Characteristics of the sample are given by various descriptive statistics.

The value of data derived from a monitoring network depends on how closely the descriptive statistics of the sample represent the population statistics and whether the resulting precision is adequate to accomplish objectives of the network. The degree to which the sample statistics represent the population statistic is given by the confidence interval. The confidence interval can be used to evaluate how representative the statistics from a given sample are and, accordingly, to adjust sample sizes to meet stated objectives. Larger sample sizes are necessary where more precise statistical estimates are required.

Data from ground-water-quality monitoring networks can provide statistical estimates of known precision of the typical quality of ground water in defined areas. Examples using data from the Kansas ground-water-quality monitoring network are presented and show how areal estimates of the median concentration for chemical constituents with 95-percent confidence intervals can be used to identify areas that have widespread water-quality problems resulting from natural or anthropogenic causes. By use of data from Kansas, examples are presented that demonstrate how the percentage of wells that exceed a given water-quality standard with 95-percent confidence intervals can be used to identify the incidence of localized water-quality problems in selected areas.

Regional ground-water-quality data also can be used to detect the presence of time trends in ground-water quality and thus can be used to document improvement or degradation through time. Various techniques of regression, correlation, and variance analysis can be used to detect changes through time. An example, based on annually collected data from the Kansas monitoring network, of how trends through time can be detected by using correlation analysis is presented. Evaluation of trends in ground-water quality provide the water manager a quantitative basis for determining whether remedial measures may be necessary to prevent or control possible waterquality problems.

\section{INTRODUCTION}

Within the last 15 years, ground-waterquality monitoring networks have been proposed or established in several States (Takasaki, 1977; Hult, 1979; Whitehead and Parliman, 1979; Spruill and Kenny, 1981; Kammerer, 1983; O'Hearn and Schock, 1984). Although ground water is used for a variety of purposes, 
monitoring of drinking-water quality is usually the focus of such networks. Generally, these monitoring networks are established because of public concern that human populations in a geographic area may be: (1) drinking water that is contaminated by current or past industrial or agricultural activities or by naturally occurring chemical constituents that may have undesirable health effects or (2) drinking contaminated water in the future because of the long-term effects of current human activities. These two concerns may be addressed by three questions--(1) What is typical water quality? (2) Does the ground water that is available meet existing water-quality standards? and (3) Are there indications that water quality is changing so that it will not meet standards in the future? Answers are needed for these three important questions so that appropriate management actions may be taken in time to mitigate immediate problems or to prevent future problems. Ground-water-quality monitoring networks can provide these answers if they are designed carefully.

The potentially detrimental effects of human activities on the quality of surface- and ground-water resources have increased public concern, which ultimately led to the enactment of the 1972 Federal Water Pollution Control Act Amendments (Public Law 92-500). The principal objective of the act was to "*** restore and maintain the chemical, physical, and biological integrity of the Nation's water." In 1974, the Safe Drinking Water Act (Public Law 93-523) was passed to assure that public drinking-water supplies would meet minimum quality standards for selected chemical constituents and that ground-water supplies would be protected from contamination by underground waste-injection procedures. In response to the directives set forth in these two pieces of legislation, the Kansas ground-water-quality monitoring network was established in 1976 as part of a cooperative program between the U.S. Geological Survey and the Kansas Department of Health and Environment.

Although ground water is used for many purposes, its use for drinking purposes forms the basis for Federal ground-water protection efforts; the U.S. Environmental Protection Agency (1984) considered the fundamental purpose of any environmental program was "***to protect public health and the environment." Drinkingwater standards, based on scientific research related to human health, provide criteria for evaluating suitability of water for drinking and act as the key for implementation of management action if necessary. Examples of standards for drinking-water quality used by the State of Kansas and the U.S. Environmental Protection Agency are listed in table 1. The Safe Drinking Water Act Amendments of 1986 (Public Law 99-339) proposed establishment of drinking-water standards for additional substances.

For water-quality standards to be effectively utilized in the management of ground-water resources, it is necessary to have a tool whereby ground-water quality can be scientifically and objectively evaluated in consideration of established standards. The State of Kansas adopted policies for "***achieving primary drinking-water standards promulgated by the Secretary of Health and Environment and ${ }^{* * *}$ protect[ing] all waters of the State against deterioration by purposeful or accidental release of spilled contaminants" (Kansas Department of Health and Environment, 1987). The Kansas groundwater-quality monitoring network is an example of an evaluation tool with which the State can quantitatively (1) establish baseline chemical quality of drinking- and irrigation-water supplies in the State's principal aquifers and (2) measure possible effects of various land-use practices that may affect ground-water quality in the State. Data produced from carefully designed monitoring networks can provide a sound basis for making effective management decisions.

This report is intended to provide wateragency personnel and other interested persons with (1) a discussion of basic statistical concepts that need to be considered when designing a regional ground-water-quality monitoring network and (2) examples of how the network in Kansas was designed and how data from this network can be useful for water-resources management.

The report is divided into two major sections. The first section describes basic principles of network design--the purpose for monitoring ground-water quality, types of 
Table 1. Drinking-water standards established by the State of Kansas and the U.S. Environmental Protection Agency for selected chemical constituents and compounds

\begin{tabular}{|c|c|c|c|c|}
\hline \multirow[b]{2}{*}{$\begin{array}{l}\text { Chemical constituent } \\
\text { or compound }\end{array}$} & \multirow[b]{2}{*}{$\begin{array}{l}\text { Unit of } \\
\text { measurement }\end{array}$} & \multicolumn{2}{|c|}{ State standard ${ }^{\mathrm{a}}$} & \multirow{2}{*}{$\begin{array}{c}\text { U.S. } \\
\text { Environmental } \\
\text { Protection } \\
\text { Agency standard } \\
\text { (Maximum } \\
\text { Contaminant } \\
\text { Level) }\end{array}$} \\
\hline & & $\begin{array}{l}\text { Kansas } \\
\text { Notification } \\
\text { Level }\end{array}$ & $\begin{array}{c}\text { Kansas } \\
\text { Action Level }\end{array}$ & \\
\hline \multicolumn{5}{|c|}{ Inorganic constituents } \\
\hline Fluoride & $\begin{array}{l}\text { Milligrams per } \\
\text { liter }\end{array}$ & 1 & 4 & $4^{\mathrm{b}}$ \\
\hline Nitrate as nitrogen & do. & 1 & 10 & $10^{c}$ \\
\hline Arsenic & $\begin{array}{c}\text { Micrograms per } \\
\text { liter }\end{array}$ & 5 & 50 & $50^{c}$ \\
\hline Barium & do. & 100 & 1,000 & $1,000^{\mathrm{c}}$ \\
\hline Cadmium & do. & .5 & 5 & $10^{c}$ \\
\hline Chromium & do. & 5 & 50 & $50^{c}$ \\
\hline Lead & do. & 5 & 50 & $50^{c}$ \\
\hline Mercury & do. & .2 & 2 & $2^{\mathrm{c}}$ \\
\hline Selenium & do. & 1 & 10 & $10^{c}$ \\
\hline Silver & do. & 5 & 50 & $20^{\mathrm{b}}$ \\
\hline \multicolumn{5}{|c|}{ Organic compounds--Pesticides } \\
\hline Alachlor & do. & 0.5 & 5 & None \\
\hline Aldrin & do. & .0031 & .031 & Do. \\
\hline Atrazine & do. & .25 & 2.5 & Do. \\
\hline Chlordane & do. & .027 & .27 & Do. \\
\hline DCPA & do. & 22.4 & 224 & Do. \\
\hline o,p'DDT & do. & .042 & .42 & Do. \\
\hline p,p'DDT & do. & .042 & .42 & Do. \\
\hline Dieldrin & do. & .00219 & .0219 & Do. \\
\hline Endrin & do. & .02 & .2 & $0.2^{\mathrm{c}}$ \\
\hline Lindane & do. & .4 & 4 & $4^{c}$ \\
\hline Methoxychlor & do. & 10 & 100 & $100^{c}$ \\
\hline
\end{tabular}


Table 1. Drinking-water standards established by the State of Kansas and the U.S. Environmental Protection Agency for selected chemical constituents and compounds--Continued

\begin{tabular}{|c|c|c|c|c|}
\hline \multirow[b]{2}{*}{$\begin{array}{l}\text { Chemical constituent or } \\
\text { compound }\end{array}$} & \multirow[b]{2}{*}{$\begin{array}{l}\text { Unit of } \\
\text { measurement }\end{array}$} & \multicolumn{2}{|c|}{ State standard $^{a}$} & \multirow{2}{*}{$\begin{array}{c}\text { U.S. } \\
\text { Environmental } \\
\text { Protection } \\
\text { Agency standard } \\
\text { (Maximum } \\
\text { Contaminant } \\
\text { Level) }\end{array}$} \\
\hline & & $\begin{array}{c}\text { Kansas } \\
\text { Notification } \\
\text { Level }\end{array}$ & $\begin{array}{c}\text { Kansas } \\
\text { Action Level }\end{array}$ & \\
\hline \multicolumn{5}{|c|}{ Organic compounds--Pesticides--Continued } \\
\hline Metolachlor & $\begin{array}{l}\text { Micrograms per } \\
\text { liter }\end{array}$ & 1.05 & 10.5 & None \\
\hline Metribuzin & do. & 17.5 & 175 & Do. \\
\hline PCB's & do. & .000079 & .000079 & Do. \\
\hline Propachlor & do. & 9.3 & 93 & Do. \\
\hline Silvex & do. & 1 & 10 & $10^{c}$ \\
\hline Toxaphene & do. & .5 & 5 & $5^{c}$ \\
\hline 2,4-D & do. & 10 & 100 & $100^{c}$ \\
\hline \multicolumn{5}{|c|}{ Organic compounds--Volatile organic compounds } \\
\hline Chloromethane & do. & 0.019 & 0.19 & None \\
\hline Bromoethane & do. & .019 & .19 & Do. \\
\hline Vinyl chloride & do. & .2 & 2 & $2^{\mathrm{d}}$ \\
\hline Chloroethane & do. & 3.7 & 37 & Do. \\
\hline Dichloromethane & do. & 5 & 50 & Do. \\
\hline 1,1-Dichloroethylene & do. & .7 & 7 & $7^{\mathrm{d}}$ \\
\hline 1,1-Dichloroethane & do. & .5 & 5 & None \\
\hline $\begin{array}{l}\text { Trans 1,2- } \\
\text { Dichloroethylene }\end{array}$ & do. & 7 & 70 & Do. \\
\hline Trichloromethane ${ }^{5}$ & do. & .5 & 100 & Do. \\
\hline 1,2-Dichloroethane & do. & .5 & 5 & $5^{\mathrm{d}}$ \\
\hline 1,1,1-Trichloroethane & do. & 20 & 200 & $20^{\mathrm{d}}$ \\
\hline Trichloroethylene & do. & .5 & 5 & $5^{\mathrm{d}}$ \\
\hline Tetrachloromethane & do. & .5 & 5 & $5^{\mathrm{d}}$ \\
\hline Bromodichloromethane & do. & .5 & 100 & None \\
\hline
\end{tabular}


Table 1. Drinking-water standards established by the State of Kansas and the U.S. Environmental Protection Agency for selected chemical constituents and compounds--Continued

\begin{tabular}{|c|c|c|c|c|}
\hline & & \multicolumn{2}{|c|}{ State standard ${ }^{a}$} & \multirow{2}{*}{$\begin{array}{c}\text { U.S. } \\
\text { Environmental } \\
\text { Protection } \\
\text { Agency } \\
\text { (Maximum } \\
\text { Contaminant } \\
\text { Level) }\end{array}$} \\
\hline $\begin{array}{l}\text { Chemical constituent or } \\
\text { compound }\end{array}$ & $\begin{array}{l}\text { Unit of } \\
\text { measurement }\end{array}$ & $\begin{array}{c}\text { Kansas } \\
\text { Notification } \\
\text { Level }\end{array}$ & $\begin{array}{c}\text { Kansas } \\
\text { Action Level }\end{array}$ & \\
\hline \multicolumn{5}{|c|}{ Organic compounds--Volatile organic compounds--Continued } \\
\hline 1,2-Dichloropropane & $\begin{array}{c}\text { Micrograms per } \\
\text { liter }\end{array}$ & 0.6 & 6 & None \\
\hline $\begin{array}{l}\text { Trans 1,3- } \\
\text { Dichloropropene }\end{array}$ & do. & .2 & 2 & Do. \\
\hline Benzene & do. & .5 & 5 & $5^{\mathrm{d}}$ \\
\hline P-dichlorobenzene & do. & 7.5 & 75 & $75^{\mathrm{d}}$ \\
\hline $\begin{array}{l}\text { Dibromochloromethane } \\
\text { (THM) }\end{array}$ & do. & .7 & 100 & Do. \\
\hline Cis 1,3-Dichloropropene & do. & .2 & 2 & None \\
\hline 1,1,2-Trichloroethane & do. & .61 & .1 & Do. \\
\hline Bromoform & do. & 1.5 & 100 & Do. \\
\hline $\begin{array}{l}1,1,2,2- \\
\text { Tetrachloroethane }\end{array}$ & do. & .17 & 1.7 & Do. \\
\hline Tetrachloroethylene & do. & .7 & 7 & $5^{\mathrm{d}}$ \\
\hline Toluene & do. & 200 & 2,000 & None \\
\hline Chlorobenzene & do. & 6 & 60 & Do. \\
\hline Ethylbenzene & do. & 68 & 680 & Do. \\
\hline $\begin{array}{l}\text { Xylene-Meta, Ortho, } \\
\text { and (or) ParaXylene }\end{array}$ & do. & 44 & 440 & Do. \\
\hline \multicolumn{5}{|c|}{ Radionuclides } \\
\hline Gross alpha & $\begin{array}{l}\text { Picocuries per } \\
\text { liter }\end{array}$ & -- & -- & $15^{r}$ \\
\hline Radium 226 & do. & -- & -- & $5^{c}$ \\
\hline
\end{tabular}

${ }^{a}$ Kansas Department of Health and Environment, written commun., November 12, 1987.

${ }^{b}$ U.S. Environmental Protection Agency, 1986b.

${ }^{c}$ U.S. Environmental Protection Agency, 1986a.

${ }^{\mathrm{a}}$ U.S. Environmental Protection Agency, 1987. 
monitoring, elements that comprise a regional ground-water-quality network, and how the objectives of regional monitoring determine the type of network to be designed. The first section also describes basic statistical principles that are useful to consider when designing a network and analyzing data from such a network. The intent of the first section is to show how these statistics may be useful in designing a network for making management decisions. The second section shows how the design principles relate to the design of the network in Kansas. This second section describes how the Kansas ground-waterquality monitoring network was designed, major features of data from the Kansas network, and ways that these data can be used.

\section{NETWORK DESIGN--SOME BASIC PRINCIPLES}

\section{Types of Monitoring and Objectives}

Ground-water-quality monitoring networks are established to accomplish specific objectives. Although networks are designed to answer one or more basic questions, as indicated previously, these questions usually are posed to answer whether either temporal or spatial change has occurred or is occurring. Monitoring networks can measure (1) point changes in time or vertical space or (2) local or regional changes through time or lateral or vertical space. Point changes are monitored in a single well or well cluster. Point monitoring often is conducted to improve the definition of geochemical processes that are affecting ground-water quality at a specific point in an aquifer. Local monitoring is defined in this report as monitoring of chemicalquality changes in several wells located in an area of 10 square miles or less. Often, this type of monitoring is conducted where a suspected contamination plume from a localized source may need to be defined so that proper remedial actions can be implemented to protect usable ground-water supplies. Regional monitoring is defined as monitoring of chemical changes in several wells located in an area of more than 10 square miles. Regional monitoring is conducted to establish general quality characteristics of water contained in areally extensive aquifers. The various types of monitoring are illustrated schematically in figure 1.

Regional networks, the subject of this report, typically are implemented by State or Federal regulatory agencies that need quantitative areal data to provide information on water-quality suitability for various uses (although usually for drinking) and information on possible deleterious water-quality trends. As pointed out in the "Introduction," this information is needed in order to apply appropriate management responses to current or future water-quality problems.

\section{Elements of Monitoring Networks}

A monitoring network can be conceptualized as consisting of five major elements. These elements are: (1) sample points, (2) sample size, (3) sample frequency, (4) watersample collection and analysis procedures, and (5) chemical constituents and properties to be monitored. Sample points are wells from which water samples are collected. Sample size is the number of sample points selected for sampling in a given area. Sample frequency refers to the number of samples obtained from a sample point during a given time period. Water-sample collection and analysis procedures refer to methods used to collect or analyze chemicalquality samples. Chemical constituents and properties to be monitored refer to the specific chemical constituents selected for sampling and analysis.

The word "sample" in this report has a statistical meaning and refers to a subset of sample points or values (for example, concentrations) randomly obtained from a larger number of points or values, which constitute the population. A water sample, on the other hand, refers to the volume of water collected from a well.

\section{Relation of Network Elements to Objectives}

Although all monitoring networks are composed of five major elements, the specific purpose or objective of a monitoring network determines how these network elements should be implemented. For example, if a network was designed to determine location and extent of contamination from industrial wastes in a particular area (that is, in an area of a few hundred acres or less), the number of sampling points should be as large as possible and in a 


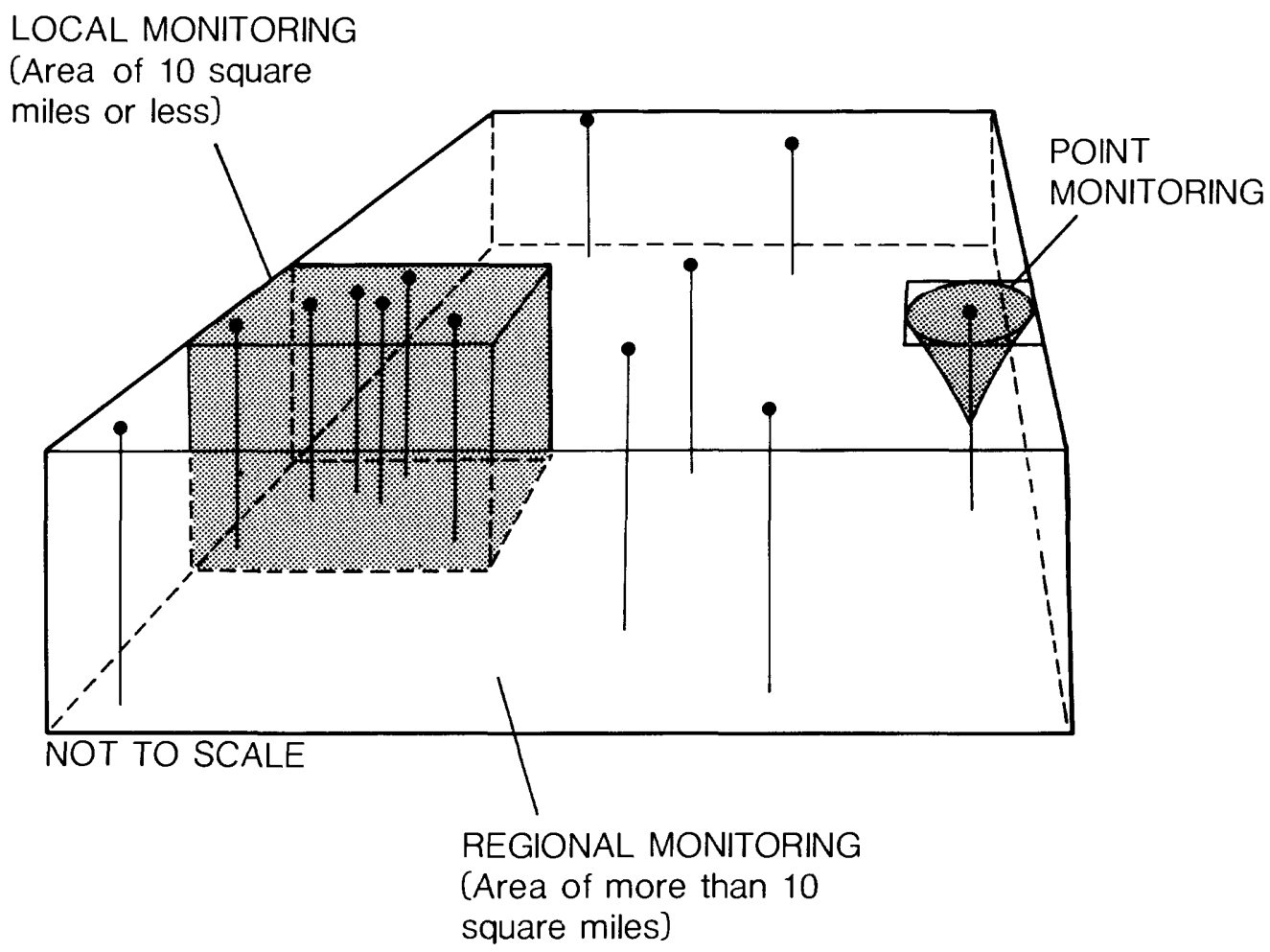

Figure 1. Schematic representation of point, local, and regional monitoring.

regular grid pattern over the area so that the areal configuration of a contaminant plume could be determined. A regular hexagonal sampling pattern was determined by Olea (1984) to be most efficient in the detection of spatial distributions, with clustered patterns the least efficient. Wells (sampling points) would be screened at various depth intervals to define the extent of vertical movement of contaminants. If the aquifer system was known to be very transmissive and susceptible to rapid changes in water levels, flushing and dilution effects might be important, and therefore, water-quality changes could be quite rapid. A network designed to detect these changes, therefore, would require frequent collection of a sample (for example, monthly or weekly). On the other hand, a network designed to describe general waterquality characteristics and broad regional time trends would require a relatively few, randomly selected, scattered sampling points and lessfrequent collection of a sample (for example, annually).

Network elements need to be customized to provide the information necessary in accomplishing the stated objectives. It is important to understand that a network designed to satisfy broad objectives probably will not be able to satisfy more specific ones.

\section{Statistical Considerations in Regional Network Design}

Water-quality monitoring networks usually are implemented to provide data for making management decisions. Data from these networks can provide a quantitative, reliable basis for characterizing water quality in an area. If analyses from a sample of wells in a region indicate large average concentrations of a particular constituent, large numbers of wells containing water that do not meet existing water-quality standards, or increasing concentrations of certain chemical constituents through time, management action may be warranted. Possible management actions might be implementation of a more localized monitoring network, provision of an alternate water supply, or regulation of land-use activities that affect ground-water quality. However, to implement appropriate management actions, a 
regulatory agency needs reliable and interpretable water-quality information so that a decision can be made that will achieve the agency's ground-water protection goals.

To be useful, the procedures used in design of a monitoring network need to provide data that are sufficient to answer questions posed by the agency. Whether the network and data produced are sufficient to answer these questions depends on whether the answers may be stated within the specified level of confidence that is desired by the monitoring agency. The following discussion presents a review of statistical concepts that are relevant to network design and confidence about estimates derived from network data.

\section{Populations and Samples}

In a statistical sense, population refers to an entire collection of objects. These objects may be people, rocks, animals, manufactured products, and in the case of a water-quality network, concentrations of various chemical constituents. It is important to understand that the population is defined by the investigator and that it consists of all of the objects that the investigator is interested in. Definition of the population is the most important aspect of design in any network because a network may yield misleading information if it is not designed specifically to provide information on the population of interest. This is illustrated in the hypothetical example that follows.

If an investigator wanted to determine the average dissolved-solids concentration of water in a specific aquifer system in a particular county, theoretically he or she could install enough wells in the county, pump the aquifer dry, store its entire contents in many 1-gallon containers, measure the dissolved-solids concentration (assuming no sampling or analytical error) in each container, and calculate the average concentration. By doing this, the investigator would have determined the true, or population average of dissolved-solids concentrations in water in the specific aquifer in the selected county.

For obvious practical reasons, investigators almost never measure a characteristic of an entire population. Instead, they try to estimate characteristics of a population with a sample--that is, a collection of some of the members from the population of interest. In this example, the sample will consist of analyses of water samples collected from many (for example, 100) different randomly selected wells. A random selection of members from the population generally is necessary for statistical analysis of a data set (Bradley, 1968). Thus, only a relatively small amount of water in the aquifer would be used to estimate dissolved-solids characteristics of all water in the aquifer. An average dissolved-solids concentration derived from this sample (called the sample mean--the average dissolved-solids concentration in water from the 100 randomly selected wells) would be an estimate of the population average (called the population mean--the average dissolved-solids concentration in water from the 1-gallon containers of all water in the aquifer, referred to in the previous paragraph).

In this example, because the aquifer and county were defined as part of the specified population of interest, it is important to randomly select sampling points throughout the entire three-dimensional space of the aquifer in the county. This could be done by setting up a three-dimensional grid and randomly selecting the desired number of grid points to be sampled. This then would require that wells be drilled and screens placed at exactly the selected points.

Because of the time and expense of drilling and constructing water wells, it is commonly desirable to use wells that are already in place and operating. Unfortunately, water wells are used for a water supply only where the water is usable. Thus, to get an idea of what dissolved concentrations are like in the entire aquifer, even sampling all available supply wells could yield a very misleading idea about water quality in the aquifer system. It is likely that many zones in the aquifer would not be sampled because they do not yield water of sufficient quantity or quality. Thus, sampling of watersupply wells only would likely yield a biased view of dissolved-solids concentrations in the entire aquifer. Such a sample would provide information about dissolved solids for only that part of the aquifer that was used for water supply.

Furthermore, inclusion of all or some types of water-supply wells can affect the estimated statistic, such as the mean, median, 
variance, or percentile (these statistics will be discussed in the next section). The quality of water is suitable depending on what it is to be used for. For example, water having a small dissolved-solids concentration [for example, less than $100 \mathrm{mg} / \mathrm{L}$ (milligrams per liter)] may be required for certain types of industrial processes, whereas water with a large dissolved-solids concentration (for example, $3,000 \mathrm{mg} / \mathrm{L}$ ) might be quite adequate for watering livestock. Therefore, if all water-supply wells are included in a sample, the estimated statistics could be much different than if only one or a few types of watersupply wells were included in the sample, even if they are all completed in the same aquifer.

Because inferences about water quality in an area are derived from a random sample, it is important for the agency or investigator to understand that the statistics derived from the sample reflect only characteristics of the particular population that was actually sampled. Just because a sample is randomly selected does not mean that the sample represents the intended population. For example, if the object of a network is to obtain information on water quality in an entire aquifer, the sample must consist of wells randomly located throughout the entire aquifer volume. If this were not done, and only existing wells were used, estimates from the sample would reflect water-quality characteristics of existing wells developed in the aquifer and not characteristics of water quality in the entire aquifer. Because of the expense of drilling and screening wells at randomly selected locations, existing water-supply wells usually are selected, and because of this, the population being sampled consists only of water-supply wells in a particular aquifer system. Such a sample would reflect characteristics of the chemical quality in water-supply wells in the aquifer system, but not the entire aquifer.

By selecting drinking-water supply wells for a network, an agency could, for example, determine areas where currently used drinkingwater supplies generally meet or do not meet drinking-water standards. Data from this type of network could detect regional water-quality problems, such as: large concentrations of selenium due to geologic factors; nitrate, due to regional agricultural use of fertilizers; or any chemical constituent that occurs due to regionalscale climatic, geologic, or anthropogenic effects.
But, such a network probably would not be able to identify areas of localized contamination that could endanger water supplies in the future or identify areas that might be useful for additional water supplies. A variety of networks with various populations defined, such as that proposed by Hult (1979) or by O'Hearn and Schock (1984), would be needed to accomplish various specialized objectives.

\section{Descriptive Statistics}

Descriptive statistics are numbers that describe certain characteristics of a sample or the population from which a sample is obtained. The mean, median, and percentile are examples of statistics that describe location in a sample or population frequency distribution (a frequency distribution is simply a graphical representation of the number of times a particular value or range of values occurs in a sample or population). The mean is the arithmetic average of all the values in a sample or population. The median is the value at which 50 percent of the values are less than and 50 percent of the values are greater than the value. A percentile is the value at which the specified percentage of values are equal to or less than the value. The location of the mean, median, and selected percentiles (the 20th, 50th, and 80 th) in a normal distribution is shown in figure 2 .

Frequency distributions exhibit various shapes (fig. 3), and certain statistics are better for describing certain characteristics of some distributions than others. The center of a frequency distribution is the location where 50 percent of the distribution is above the point and 50 percent is below the point. If the distribution is normal, most of the values cluster around this point. Also, if the sample or population has a normal distribution (fig. $4 \mathrm{~A}$ ), both the mean and median would be located at the central part of the distribution. For a positively skewed distribution (fig. $4 \mathrm{~B}$ ), the mean and median are not in the same location. Only the median is located at the center of the distribution, whereas the mean may be located far from the center of the distribution. If typical is defined as the center of the distribution and the population distribution is normal, the sample mean or median could approximate the typical value lalthough the mean is the preferred estimator for normal distributions (Wonnacott and Wonnacott, 1977)I. If the population sampled is 


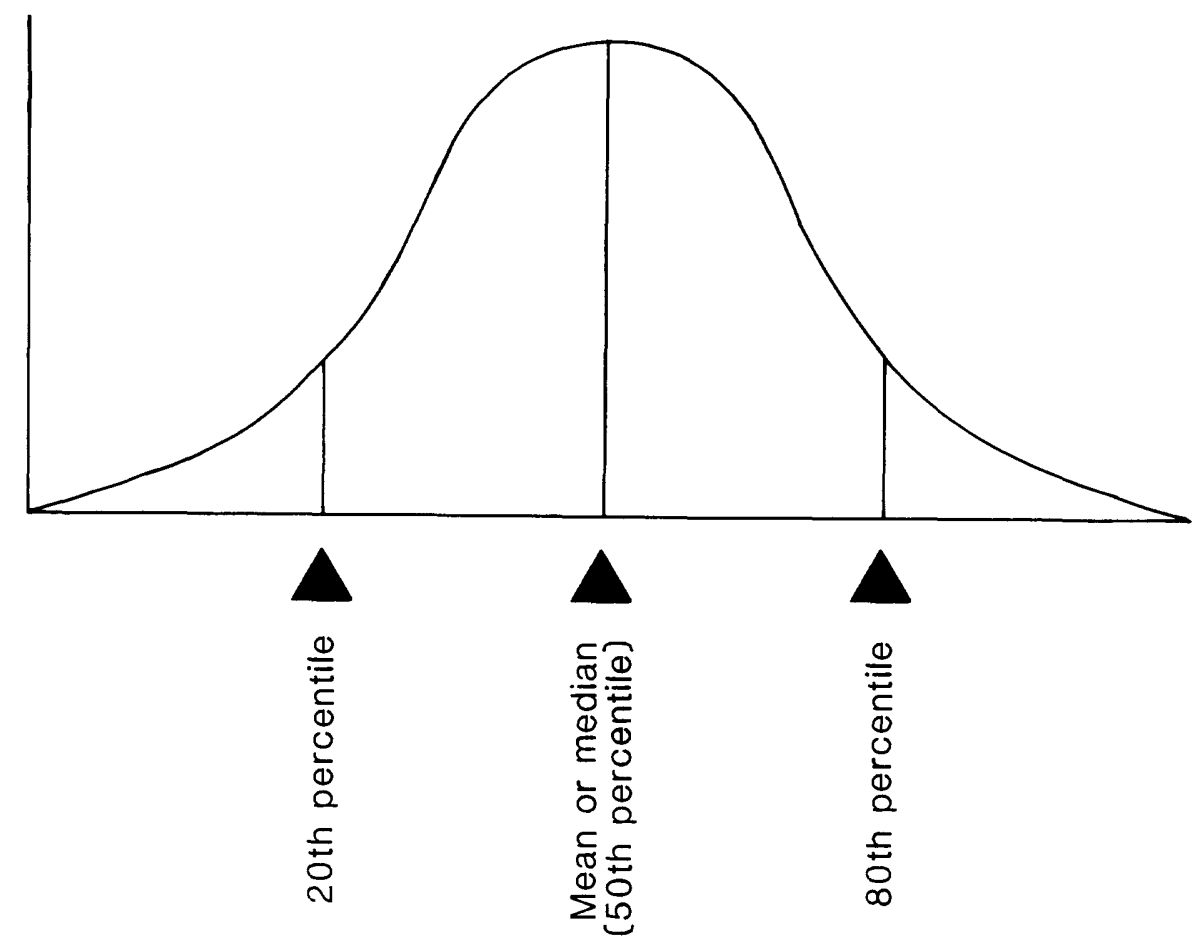

Figure 2. Location of mean, median, and 20th, 50th, and 80 th percentiles in a normal distribution.

skewed, however, the mean would not be located at the center of the distribution. For skewed distributions, as much as 99 percent of population distribution can "lie just below the mean" (Bradley, 1968). The median would better represent the typical value for such a distribution. Because water-quality data often are skewed (Montgomery and others, 1987), the median generally would better represent typical concentrations than the mean.

In addition to location statistics, the range, standard deviation, variance, and interquartile range are examples of statistics that describe the variability of a sample or population frequency distribution. These statistics are a measure of the spread or dispersion of values in a sample or population. The range is the difference between the smallest and largest value. The standard deviation is the square root of the variance. The variance is the average of the square of deviations of values about the mean of all the values. The interquartile range is the difference between the lower (25th percentile) and upper (75th percentile) quartile.
Statistics that are used to estimate variability of a population are useful to water managers because they can be a good initial indicator of where problems probably do or do not exist. For example, a sample consisting of analyses of chloride from water samples collected from 50 randomly selected supply wells could have chloride concentrations ranging between 25 and $75 \mathrm{mg} / \mathrm{L}$. Because the drinking-water standard for chloride is $250 \mathrm{mg} / \mathrm{L}$ and is so much larger than the observed maximum of $75 \mathrm{mg} / \mathrm{L}$, the range, in this example, would be good evidence that chloride concentrations in water from supply wells in the area would be suitable for drinking purposes.

\section{Inferential Statistics}

The value of the data derived from a monitoring network depends on how close the sample statistics estimate the population statistics. Investigators infer from the available sample how representative the sample statistics are of the population statistics. The reliability of the statistics generated from the sample depends on the shape and variability of the population 

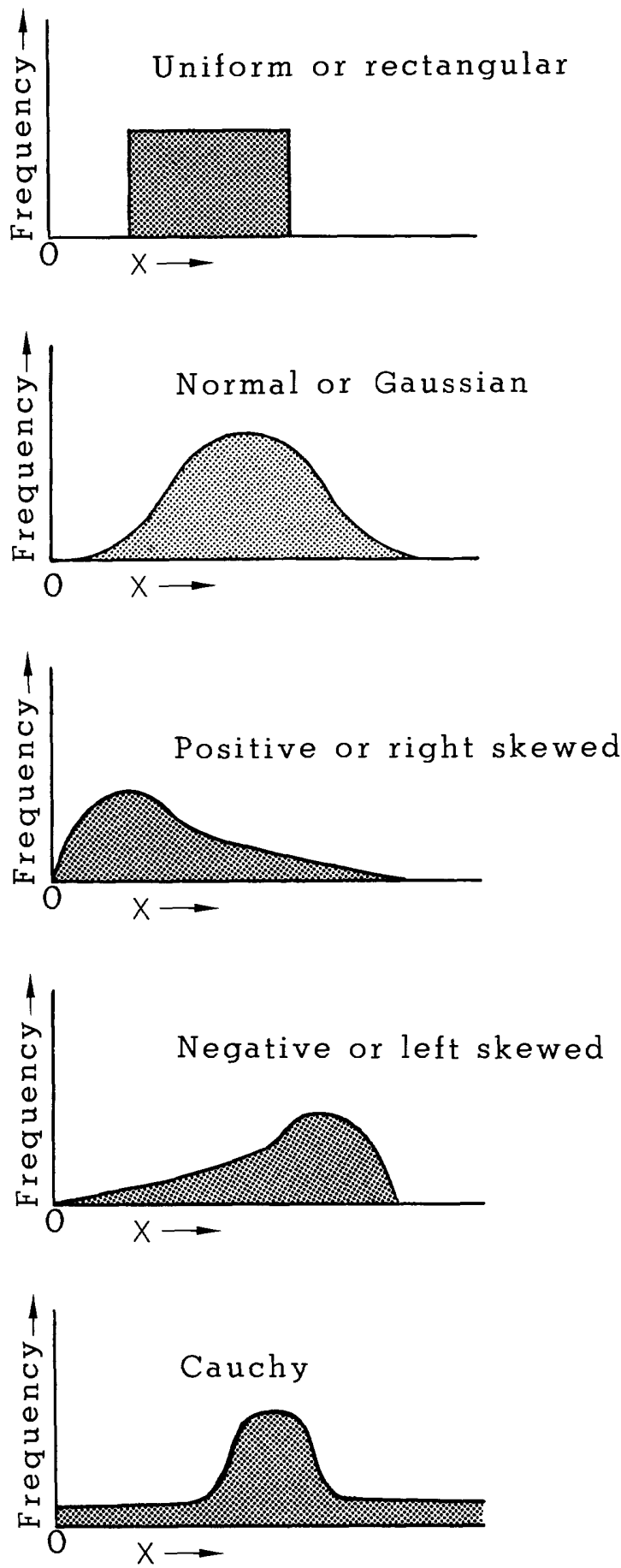

Figure 3. Shapes of selected frequency distributions.
A

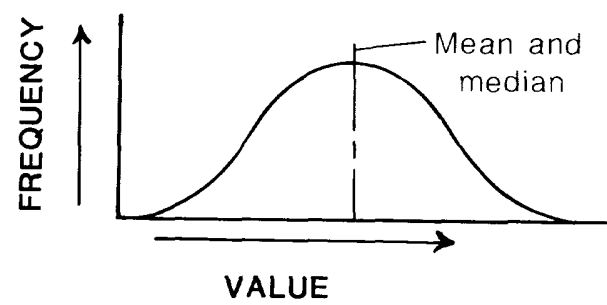

Non-normal distribution

(positively skewed)

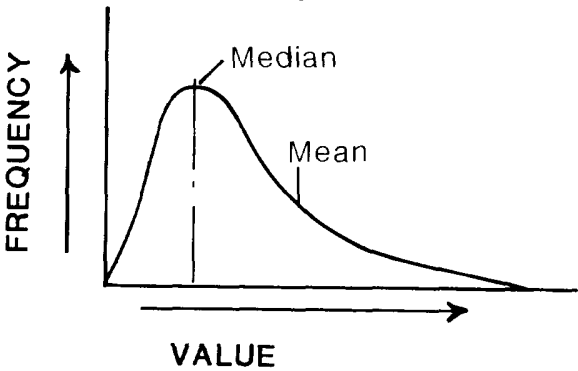

Figure 4. Examples of (A) normal and (B) positively skewed frequency distributions and relative location of mean and median values.

distribution from which a sample was obtained and the size of the sample used to obtain the estimate.

Unfortunately, researchers almost never know the shape of the population distribution; assumptions about the shape of the population frequency distribution usually are based on the shape of the sample frequency distribution. If the shape of the population distribution is different from what it is assumed to be, statistics from the sample can be misleading. This is because the probabilities of getting observations in a given range are based on the shape of the probability function [the function that associates probabilities with various numerical values that the random variable can assume (Iman and Conover, 1983)]. If, for example, one were trying to estimate the probability of the occurrence of the value 1 in a population from a sample and it was assumed that the distribution was as shown in figure 5 , the probability would be 0.1 or about 1 in 10. If the actual, or population, distribution was, however, as shown in figure 5 , the true probability of occurrence would be 0.55 or about 1 in 2 , a much different probability. Assumptions about the population distribution are, therefore, extremely important when making inferences from the sample. 




Figure 5. Probability function of $X$ for actual and assumed sample distributions.

Statistical methods that assume that the distribution is normal or some other distribution shape are termed parametric statistical methods. Statistical methods that do not assume a normal (or any other) distribution are termed nonparametric statistical methods. Both types of techniques can be valuable in network design and data analysis if they are applied correctly. It is imperative that assumptions about the population distribution be made carefully because the probabilities associated with any statistical estimate depend on whether the assumptions about the population are correct or not. In general, however, because investigators usually do not know the shape of the population distribution from which a sample was obtained, it is usually safest to use nonparametric statistical procedures because of fewer assumptions that have to be made.

Sample size can also affect the reliability of inferences made about populations. Whereas a sample estimate of a particular population statistic is the best that the researcher can do in inferring information about the population, it is possible to make wrong inferences about the population if the available sample, by chance, is not representative. This is particularly true with small samples consisting of only a few observations. This is demonstrated in the following example.

The degree of confidence that one has that the sample mean, median, or percentile is representative of the population may be quantified by construction of confidence intervals. A confidence interval can be constructed about any sample estimate that defines the maximum and minimum values that will include the true population statistic with a specified level of confidence. If the population being sampled were, for example, chloride concentrations in water from all stock wells in a county and the county had 100 stock wells, water tapped by these 100 stock wells would be the population. However, because the budget was limited, only a part (seven wells in this hypothetical example) of the population could be sampled. Analyses of water samples collected from the seven randomly selected stock wells had chloride concentrations of $10,10,30,35,50,50$, and $950 \mathrm{mg} / \mathrm{L}$ (fig. 6A) and would constitute the sample to be used to estimate the true median $(50 \mathrm{mg} / \mathrm{L})$ of the entire population of 100 chloride values (fig. 6B).

As seen in figure 6, the sample estimate of population median $(35 \mathrm{mg} / \mathrm{L})$ for the seven wells in the sample is smaller than the true population median $(50 \mathrm{mg} / \mathrm{L})$. The sample estimate was not exactly the same as the true population median. A larger sample of 25 wells, for example, would have yielded a more precise estimate of the true population median than only 7 wells; in general, large sample sizes yield estimates that are closer to the true population parameters than do small sample sizes. 



Figure 6. Examples of (A) sample estimate of population median and (B) true population median.

However, to define the range of values about a sample estimate of the median that includes the true population median with 95 -percent confidence, a confidence interval can be constructed according to techniques given in Conover (1980). The 95-percent confidence interval for the sample of the seven wells is 10 to 50 . On the basis of a sample of seven wells, the true population median, with 95 -percent confidence, is no larger than 50 and no less than $10 \mathrm{mg} / \mathrm{L}$. A larger sample, consisting of 10 or 15 wells, likely would narrow this range of values, and the estimate of the median would be more precise than the estimate made on the basis of seven wells. If a water-quality standard was 20 $\mathrm{mg} / \mathrm{L}$, even though the sample median based on seven wells was $35 \mathrm{mg} / \mathrm{L}$, a sample size larger than seven wells would be necessary to conclude that the true population median exceeded the water-quality standard.
Although the median of a sample in a region yields useful information to the water manager about the typical quality of groundwater supplies, it does not provide information about the percentage of wells that exceed a standard in a region. Other statistics besides the median, such as percentiles or proportions, also can be quite informative. The median reveals much information about typical quality but indicates nothing about the occurrence of outlier concentrations--the extremely large concentrations in a positively skewed distribution.

The percentage of wells that yield water with concentrations that exceed a regulatory maximum value provides valuable information to management agencies that would reflect the severity of a problem. The sample median concentration can be significantly less than a 
given regulatory standard, suggesting, in general, that no problem currently exists. However, a substantial percentage (for example, 10 percent or more) of wells in a sample could yield water with large concentrations that are greater than a specified standard. The actual percentage that would be considered unacceptable would be determined by the management agency.

A confidence interval can be constructed about the percentile according to the technique described in Conover (1980) or Rohlf and Sokal (1969), using the available sample, to determine what the range of the true percentage in the population might be. A 95-percent confidence interval that indicated the true percentage was between 8 and 12 percent might be acceptable to a water-management agency. On the other hand, if the 95-percent confidence interval indicated that the true percentage could range between 4 and 40 percent, this would be an indication that a larger sample needs to be collected to determine more accurately what the true percentage of wells really was that would yield water with concentrations greater than the standard. If $\mathbf{4 0}$ percent of the wells in an area really yielded water with concentrations greater than the standard, this might be construed by a management agency as an environmental problem.

The concept of confidence interval is useful for scientists and water managers because it yields quantitative information on how well the sample represents the particular population. If the confidence interval is large, then more sampling may be required to improve the definition of a potential water-quality problem. The sample size can be adjusted to meet requirements of a particular water-management agency. An example of constructing a confidence interval about a sample median is shown in Appendix I.

\section{Network Elements--Statistical Aspects}

The importance of network elements has been mentioned. The statistics that may be derived from a network depend on how the elements are pieced together. The following list briefly discusses statistical aspects that need to be considered when defining features of network elements:
(1) Sample points--all selected sample points need to have enough well-construction, geologic, and land-use information available so that as many variables as possible may be used in a causal analysis, as well as being able to improve the definition of the population of interest. If the purpose of the monitoring network is to describe the chemical quality of ground-water supplies of a specified area, then it may not be necessary to identify particular formations or aquifers. However, if the aquifer units are identified, then these data can be used to segregate zones that have particular waterquality problems. If the sample is not segregated into categories [or strata, as they are statistically referred to (see Snedecor and Cochran, 1967 or Nelson and Ward, 1981)], the variability of the sample most likely will be great, and the data will be of less use to the water manager. Although it is desirable to divide the population into homogeneous categories (which results in more precise estimates), relatively more sample points will be required. Generally, it is desirable to record as many characteristics associated with a particular sample point as possible, in that way this ancillary data possibly can be used for evaluating effects of factors such as wellconstruction characteristics, hydrologic variation, or land use on water quality.

Various types of sampling schemes (simple random, cluster, systematic, and stratified random) have been discussed by Cochran (1964), Snedecor and Cochran (1967), 'Taylor (1977), and Nelson and Ward (1981). The use of different sampling schemes is an attempt to get as much information as possible with the least number of sampling points. Generally, sampling schemes are chosen to yield estimates of the population mean with the least error possible. Less sample variance will result in more precise estimates of the mean.

The type of sampling scheme to be used depends on the areal distribution pattern of the variable (concentration of a chemical constituent). Many researchers (Taylor, 1977; Nelson and Ward, 1981; Olea, 1984) recommend either a systematic (or modification--see Taylor, 1977 ) or stratified random pattern where a nonrandom pattern of the variable exists Isuch patterns exhibit properties of autocorrelation"***things located near one another are more likely to be alike than objects far apart" (Taylor, 
1977)]. Methods of testing whether a nonrandom pattern is present are discussed in Taylor (1977) and Davis (1987). However, because most statistical analytical methods require randomly selected sampling points (that is, they must be independently selected), a simple random design is the only method that fulfills this requirement (Taylor, 1977). In addition, sampling schemes other than simple random are directed at yielding more precise estimates of population means, which, as has been discussed, may not be particularly meaningful for skewed populations. The researcher or management agency may be interested in other statistics, such as selected percentiles, as well.

Although sampling schemes, such as systematic or stratified random, may be more efficient at detecting the presence of nonrandom patterns or yielding unbiased estimates of the mean, such sampling schemes might not yield unbiased estimates of all statistics. A simple random sample, on the other hand, can be used to estimate all statistical properties of the selected population although it may be very inefficient (requiring many water samples) to do so.

(2) Sample size--sample size needs to be large enough to describe areal water-quality characteristics with known precision at specified levels of confidence. Assuming the variables of interest are normally distributed (usually, but not always, an incorrect assumption when considering water-quality data), simple computational formulas can be applied to determine the proper sample size required to estimate a mean with a specified degree of error. These techniques are discussed in Snedecor and Cochran (1967) and Nelson and Ward (1981). An example of the procedure is included in Appendix IIA. However, because the distribution of most water-quality variables usually is skewed and the median would more accurately represent typical features of the variable than the mean, Gilbert (1987) has presented a computational formula to estimate sample size required to estimate a population median with a known degree of confidence. An example of this method is presented in Appendix IIB. Both methods require a preliminary sample of the population of interest so that the final sample size necessary to achieve the desired precision of the estimated mean or median can be derived. Where sample points are located close together, spatialcorrelation effects might be active, and sample sizes can be adjusted using procedures discussed in Nelson and Ward (1981).

Where the population distribution is not known, Spruill and Candela (1990) have presented a method to estimate the sample size necessary to estimate any quantile with a desired precision. A quantile is a particular location in a frequency distribution, such as the median (the 50th percentile or 0.5 quantile), a decile (10th percentile or 0.1 quantile), the lower quartile (the 25th percentile or 0.25 quantile), and so on. The method requires a large sample ( 50 or more observations is desirable) to be available initially, but sample size can be reduced to the size needed to achieve the desired sample precision. An example of the method is given in Appendix 1 II.

(3) Sample frequency--samples need to be collected frequently enough to describe temporal water-quality characteristics with known precision at specified levels of confidence. Seasonality might be important in shallow, permeable aquifers (Montgomery and others, 1987); therefore, chemical quality could be variable through time. The objective of the monitoring network will affect the frequency of collection of water samples. If water-quality problems occur seasonally (for example, nitrate concentrations) and seasonal problems are considered important by the water-management agency, then sampling needs to be frequent enough (for example, quarterly) to detect this variability. If the purpose of the network is to determine only long-term trends, then lessfrequent sampling could be appropriate. However, for trend analysis, it is necessary to limit the sampling periods to the same season every year so that seasonal effects would be minimized, or if sampling were more frequent than annual, seasonal effects would need to be eliminated statistically (Montgomery and others, 1987).

(4) Sample collection and analysis procedures--samples need to be collected and analyzed according to standard or accepted procedures that cause the least amount of variation possible. All procedures should be documented when using a long-term network so that a way of correcting data for long-term trend analyses is provided. For example, if a particular chemical constituent is analyzed by one particular method for 5 years and then another is subsequently used, data analysts must know this 
in order to correct for changes in accuracy and precision of the reported concentrations.

(5) Chemical constituents or properties-selected constituents or properties need to reflect the most likely encountered pollutants. For example, sampling for pesticides logically would be included in irrigated agricultural areas that use shallow water supplies but might be left out in areas that use deep wells or in areas that are not agricultural. Generally, major and minor constituents (as defined in Davis and DeWiest, 1966) should be sampled at all sites in a network to provide a data-quality check (see Hem, 1985). Ultimately, the actual chemical constituents selected depend on what the data are to be used for.

\section{Systems Approach to Network Design}

Design of a monitoring network can be complex when considering various network elements and the selection of where, how many, and how frequently water samples should be collected. Recent papers by Hsueh (1987) and Hsueh and Rajagopal (1988) have presented design approaches that incorporate concepts of optimization theory and attempt to quantitatively account for all significant factors in the design of a cost-effective monitoring network. Basically, this optimization approach provides that the objective function, to sample a given well or not, can be stated as a function of various sampling considerations (precision of the estimate for a given chemical constituent or concentration relative to a water-quality standard), health effects (expressed as a ratio of constituent concentration to a constituent waterquality standard), and budget constraints.

Although a systems approach can account simultaneously for many varied factors, the procedure, as presented in Hsueh and Rajagopal (1988), assumes normally distributed data. As noted, chemical constituents in ground water usually are nonnormally distributed so that resulting decisions about sampling a given well or not will be affected to some degree by this fact. Because water-quality variables are usually positively skewed and exhibit a large variance, relative to normal distributions, the resulting samples sizes actually could be conservative. However, this means that more sampling points (implying more time, effort, and cost) than necessary could be recommended to achieve the intended level of statistical description
Rajagapol (1987) has presented a method for removal of outliers, but this could have the opposite effect of making resulting sample sizes inadequate for positively skewed data.

Sample statistics probably are the most important part of the information gathered from a monitoring network because they are used to make management decisions, and networks can give different statistical information depending upon how the various elements are constructed to compose the final network. Regardless of the method used to design the network, it is imperative that the statistics obtained from a network be adequate enough to accomplish the intended network purpose or objectives.

\section{Methods of Data Analysis}

The objectives of a monitoring network determine what method of data analysis is warranted. Three objectives of a regional monitoring network are listed in the following paragraphs along with the methods that would be appropriate to meet them.

\section{(1) Objective--To detect specific local problems in an area}

Method--Where the objective is to locate specific problem areas, map-analysis techniques (Davis, 1987) probably are most effective. Olea (1984) has presented an excellent description of the use of universal kriging for designing a network to describe areal features of a particular variable. Essentially, the technique requires: (1) establishment of the acceptable prediction error (standard error) at any given point on a map of a particular area; (2) sampling of the waterquality variable in two-dimensional space so that the spatial function can be described; (3) evaluating the resulting standard error; and (4) if the desired standard error is achieved, evaluation and redesign of the most efficient network (description of the water-quality variable within the desired standard error with the fewest sample points possible). Because water-quality variables usually are not normally distributed, logarithmic transformation of the data may be required. These techniques are described in Dowd (1982).

Maps showing spatial distribution of concentrations of particular chemical constituents and standard error can be produced from such networks. The optimum sampling 
pattern for networks designed to detect localized problem areas (that is, they are designed to detect nonrandom patterns) is regular or systematic. Although data from this type of network could be used for a general areal statistical description, such estimates could be biased (as discussed previously) because the sampling procedure is not random. This potential problem could be eliminated by randomly obtaining a subsample from the area of interest.

\section{(2) Objective--To statistically characterize} water quality in an area

Method--Where the objective of the network is to provide general statistical information on water quality, a simple random sample of selected water-supply wells, specified geologic strata or wells of selected depth, and other specified categories (or strata) can be used to describe the general characteristics of the frequency distributions of various chemical constituents in a selected area. Statistical information would include estimates of typical concentrations, such as the median or mean, estimates of variability, or estimates of percentages of wells that exceed specified use standards. This type of network can provide data for determining where water-quality problems already exist and for establishing baseline characteristics of water quality in the area for the desired population. Various statistical techniques for describing water-quality data from such networks include presentation of data in the form of tables, histograms, stem-and-leaf diagrams, boxplots, construction of confidence intervals, or other methods. Examples of how to represent and interpret these data are given in general texts, such as Snedecor and Cochran (1967) and Conover (1980) and can be done with several available computer software packages.

\section{(3) Objective--To detect possible trends in water quality}

Method--A major objective of most monitoring networks is to detect water-quality trends through time. A network designed to statistically characterize water quality in an area could be used for this purpose. Trends through time can be determined in either single wells or in several wells in an area. Methods of correlation or regression usually are used to determine trends. Because ground-water quality can exhibit both seasonality and serial dependence [characteristics that violate requirements of correlation techniques (Conover, 1980)], data first needs to be adjusted before trends can be evaluated. These considerations are discussed in Montgomery and others (1987).

For data from single wells, correlation methods, such as Spearman's rho or Kendall's tau, could be applied to data that have been collected during the same season or time period every year. Collection of data during the same period every year would minimize seasonal effects. For several wells in an area, annual regional medians (or any selected quantile) could be analyzed by these correlation methods to determine the presence of trends through time.

Where daily, monthly, or quarterly data are to be analyzed, seasonal or serial dependence effects (see Montgomery and others, 1987) can be adjusted by statistically comparing through time only the same seasons or the particular seasonal- or serial-dependence effect. Hirsch and others (1982) have presented a technique, which they refer to as the seasonal Kendall test for trend, that can correct for such problems. Other trend tests are presented in Conover (1980).

\section{DESCRIPTION OF KANSAS GROUND-WATER-QUALITY MONITORING NETWORK--AN EXAMPLE}

\section{Background and Network Objectives}

The Kansas ground-water-quality monitoring network was established in 1976 as part of a cooperative program between the U.S. Geological Survey and the Kansas Department of Health and Environment. The principal objectives of the network were to: (1) Describe water-quality characteristics for principal aquifers of the State, (2) identify areas of potential pollution in the principal aquifers of the State; and (3) evaluate the data from the network with respect to State water-quality standards and Federal water-quality standards specified by the Safe Drinking Water Act. The location and available information on sites in the network sampled between $1976-80$ are presented in Spruill and Kenny (1981). The distribution of wells sampled during $1976-81$ is shown in figure 
7. Originally, the network was composed of approximately 500 public-, irrigation-, domestic-, and stock-supply wells throughout the State that were sampled on an annual basis. Approximately 4 to 8 wells per county were sampled.

In 1982, because the cost of collecting data from so many wells was increasing and no additional funding was available, the network was reduced to 250 wells to be sampled annually. The State was divided into 14 ground-water regions (fig. 8) so that the data could be evaluated on a regional, rather than a county, basis. These regions are similar to physiographic regions presented in Schoewe (1949) and are relatively homogeneous with respect to geology, land-use, topography, and water-use characteristics. Wells included in the revised network yield water from one of seven principal aquifers in the State (fig. 9), described in Bevans and others (1985). Generally, all of the principal aquifers in Kansas may yield more than $10 \mathrm{gal} / \mathrm{min}$ to individual wells and typically yield more than $50 \mathrm{gal} / \mathrm{min}$.

Most small domestic and stock wells that are developed in aquifers with small yields (10 $\mathrm{gal} / \mathrm{min}$ or less) were removed from the network. As a result, virtually no wells were sampled from ground-water region 2 after 1982, and small supply wells in other regions that were developed in aquifers with small yields were removed from the network. It should be noted that even though the Douglas aquifer, shown in figure 9, extends through ground-water region 2 , it generally contains very mineralized water throughout most of the area south of southern Douglas County. Consequently, the aquifer is used primarily for public supplies in only Douglas and Leavenworth Counties. To allow for a minimal regional sample size (5), however, wells in the Douglas aquifer in Douglas County (partially in region 2) are grouped with region 1 in this report.

Because of changes made in the composition of the monitoring network, the objectives of the network were revised. Current (1988) objectives of the network are to:

(1) Describe regional water-quality characteristics of public- and irrigation-water supplies from principal aquifers in 13 defined ground-water regions of Kansas.

(2) Detect possible annual changes or long-term trends in water-quality characteristics of public and irrigation supplies from principal aquifers in 13 defined ground-water regions of Kansas.



Figure 7. Location of wells in Kansas ground-water-quality monitoring network، 1976-81. 


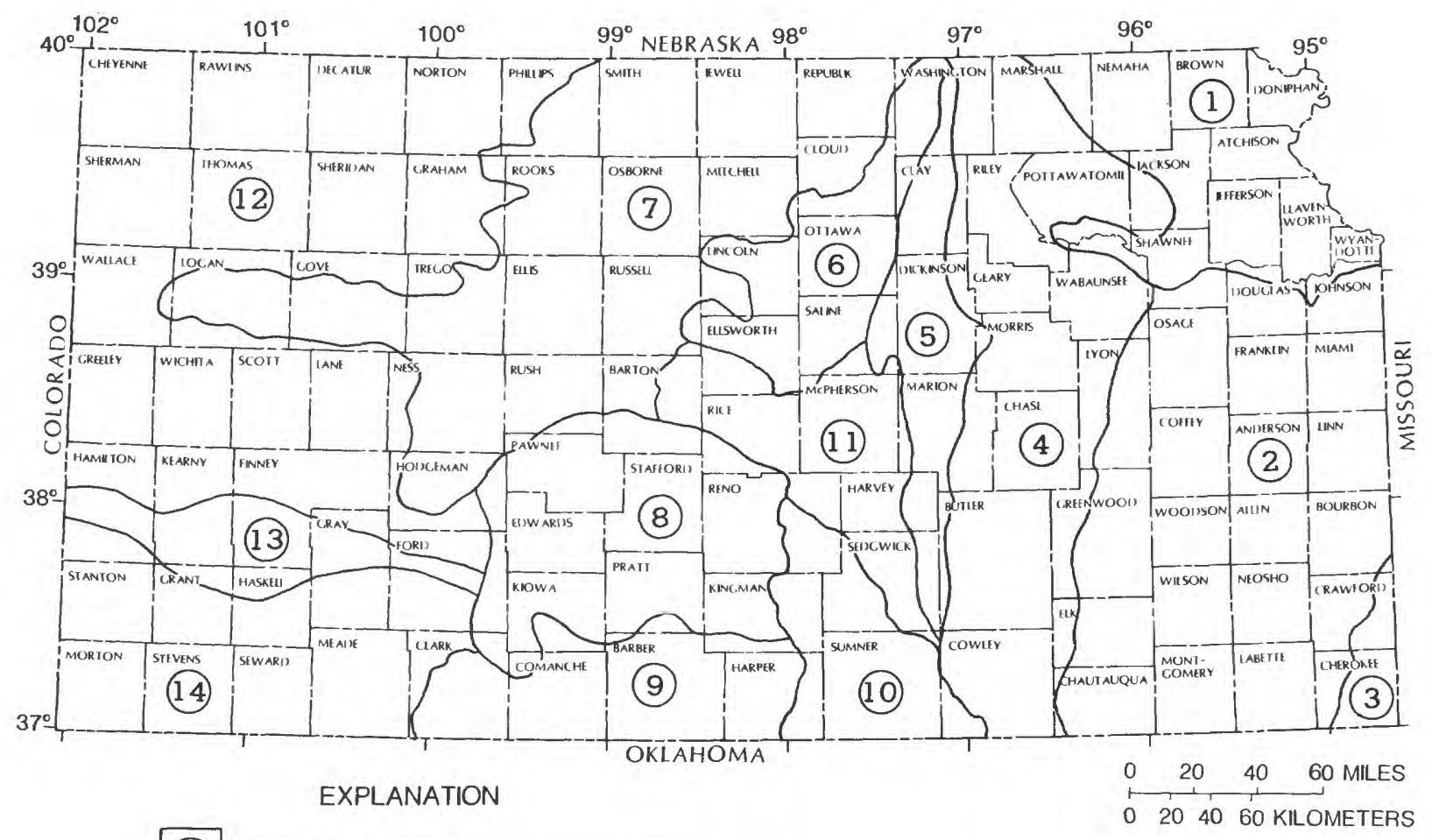

(1) GROUND-WATER REGION AND NUMBER

Figure 8. Ground-water regions of Kansas (from Spruill, 1983).

The distribution of wells sampled during the 1988 water year (October 1987 through September 1988) is shown in figure 10.

\section{Network Elements}

\section{Sampling Points}

The current network (1988) is composed primarily of public- and irrigation-supply wells in principal aquifers of the State as described in Bevans and others (1985). Wells were selected from files of the Kansas Department of Health and Environment (Topeka) and had complete well-construction information or were wells included in the pre-1982 network that had adequate well-construction information. Publicsupply and irrigation wells were selected as the principal sample points because they yield from principal aquifers currently used as drinkingwater sources, usually have a longer monitoring life than smaller domestic- or stock-supply wells, have more reliable information on well construction, and are consistently accessible for sampling over long time periods. About 70.5 percent of wells in the network are used for public supply, and 19.8 percent are used for irrigation. Some domestic and stock wells in principal aquifers were retained from the original network if 5 or more years of record since 1976 were available and if construction and water-use information were available. About 7.8 percent of wells in the network are used for domestic purposes and 1.9 percent for stock and industrial purposes. As many public-supply and irrigation wells as possible were retained from the original network to maintain long-term continuity of data. Well depth was not considered except where it was necessary to determine the producing aquifer.

The location of sample points was selected randomly by overlaying a numbered grid having 36 square miles per grid node on each groundwater region and then selecting the number of sample points as derived from the method described in the following section on "Sample Size." In an attempt to make data collected from the network as useful as possible, a variety of site information, including principal land use within 200 feet and within 1 mile of each well, was recorded for wells in the current network. This type of information can be used to determine possible causal factors associated with the occurrence of certain chemical constituents.

The Kansas ground-water-quality monitoring network is designed to yield 


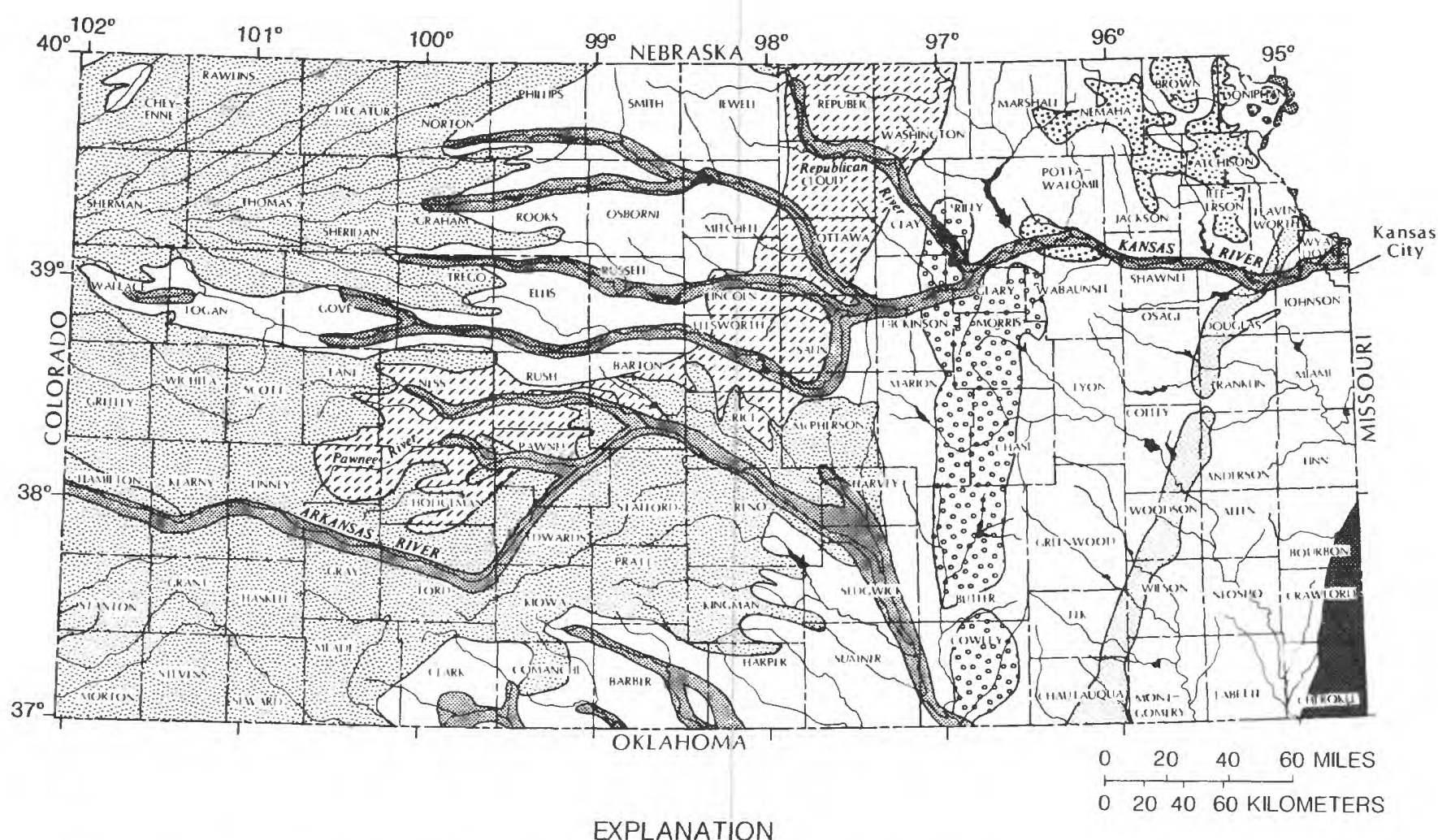

ALLUVIAL AQUIFER--Quaternary fluvial deposits of clay,
silt, sand, and gravel. Generally unconfined

GLACIAL-DRIFT AQUIFER--Pleistocene glacial deposits of clay, silt, sand, and gravel. Generally unconfined

HIGH PLAINS AQUIFER-Fluvial and eolian deposits of clay, silt, sand, and gravel of Cenozoic age. Generally unconfined

GREAT PLAINS AQUIFER--Dakota and Cheyenne Sandstones of Cretaceous age. Generally unconfined

\section{:}

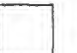

DOUGLAS AQUIFER--Channel sandstones of Douglas
Group of Pennsylvanian age. Generally unconfined

OZARK AQUIFER--Weathered and sandy dolomites of Arbuckle Group of Cambrian and Ordovician age. Confined

NOT A PRINCIPAL AQUIFER

Figure 9. Principal aquifers in Kansas (modified from Bevans and others, 1985).

information only on ground-water supplies being used in principal aquifers in each of 13 defined ground-water regions. This approach provides general areal information that can be used to describe the quality of those parts of aquifers that provide irrigation and public supplies. It does not necessarily yield information on the quality of localized aquifer systems or other localized parts of the principal aquifer. To do this would require inclusion of many more wells.

The current network provides data that can be used to describe water quality of major aquifers used for public-water supplies in most of the State and can measure major changes in areal water quality through time, which is important for evaluating possible degradation or improvement in water quality. It is important to emphasize that although areal trends can be evaluated using data collected beginning in $\mathbf{1 9 7 6}$ through 1987, only comparable populations should be included in the analyses. Thus, to evaluate trends through the entire period, only public-supply and irrigation wells in principal aquifers could be used validly in the evaluation.

Within the context of the ground-waterclassification system described in the Kansas ground-water protection strategy (Kansas Department of Health and Environment, 1987), the network provides a basis with which to measure changes in quality and compliance with standards for class-I aquifers (aquifers that provide water containing no more than $500 \mathrm{mg} / \mathrm{L}$ 


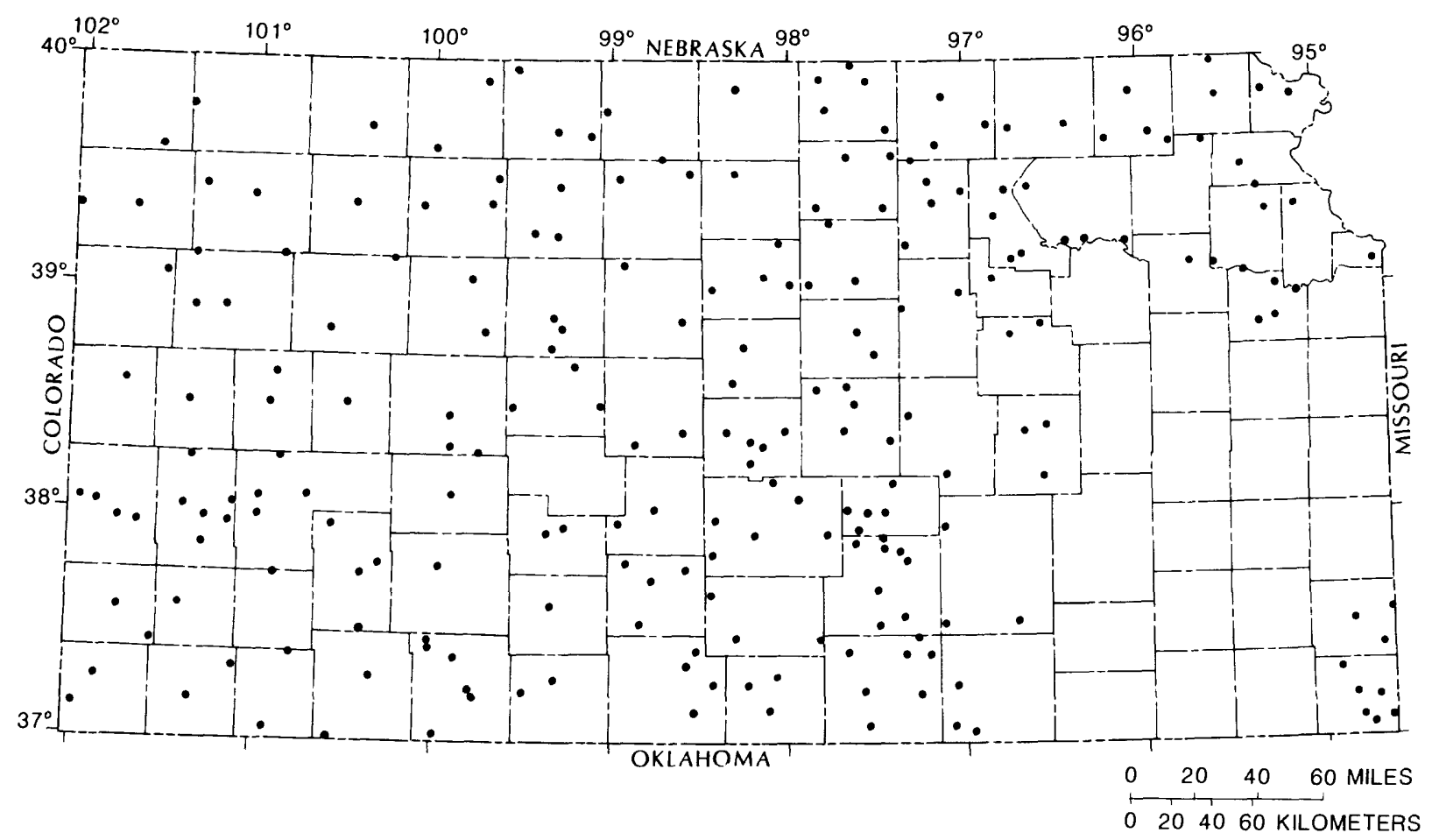

Figure 10. Distrubution of wells in Kansas ground-water-quality monitoring network sampled during 1988 water year.

chloride or $1,000 \mathrm{mg} / \mathrm{L}$ dissolved solids) or classII aquifers (aquifers that provide water containing from 500 to $5,000 \mathrm{mg} / \mathrm{L}$ chloride or 1,000 to $10,000 \mathrm{mg} / \mathrm{L}$ dissolved solids).

\section{Sample Size}

Sample sizes for the current monitoring network were determined from data collected from network wells sampled before 1981. The sample sizes for each defined ground-water region and aquifer system (table 2) were derived from the Neyman optimal allocation method (Snedecor and Cochran, 1967; Nelson and Ward, 1981) to describe a statewide mean dissolvedsolids concentration. The method is demonstrated in Appendix IV.

On a statewide-basis, dissolved-solids concentrations exhibited a normal distribution, allowing application of the Neyman method. Dissolved-solids concentration was chosen as a basis for sample-size allocation because it is used for aquifer classification in Kansas. Approximately 250 wells could be sampled annually with the current budget. The actual number of wells sampled in any year may vary because of the availability of certain wells for sample collection. Generally, between 90 and 95 percent of wells in the network are sampled annually.

\section{Sample Frequency}

All wells in the current network are sampled for all major constituents (including calcium, magnesium, sodium, potassium, alkalinity, sulfate, chloride, nitrate, and phosphorus) and physical properties (specific conductance, $\mathrm{pH}$, and water temperature) once per year between late May through September. Samples for selected organic determinations are collected from 40 to 50 selected wells in the network on a rotating basis so that all or most wells in the network will have been sampled for organic compounds (those having primary drinking-water standards) and gross alpha and radium 226 within a 5 -year period. Samples for all network wells in ground-water region 3 are sampled annually for trace metals and radionuclides (radionuclides are known to occur at relatively large concentrations in this region).

\section{Sample Collection and Analysis Procedures}

Water samples are collected by personnel of the U.S. Geological Survey. Methods used to collect water samples for inorganic constituents 


\begin{tabular}{|c|c|c|c|c|}
\hline $\begin{array}{l}\text { Ground-water } \\
\text { region (fig. 8) }\end{array}$ & $\begin{array}{c}\text { Principal aquifer } \\
\text { (unconsolidated) } \\
\text { (fig. 9) }\end{array}$ & Sample size & $\begin{array}{c}\text { Principal aquifer } \\
\text { (consolidated) (fig. 9) }\end{array}$ & Sample size \\
\hline 1 & $\begin{array}{c}\text { Glacial-drift and } \\
\text { alluvial }\end{array}$ & 13 & $\begin{array}{l}\text { Douglas (includes } \\
\text { wells from region } 2 \text { ) }\end{array}$ & 3 \\
\hline 2 & No principal aquifer & 10 & See text (p. 18) & 0 \\
\hline 3 & do. & 0 & Ozark & 9 \\
\hline 4 & Alluvial & 6 & $\begin{array}{c}\text { Chase and Council } \\
\text { Grove }\end{array}$ & 10 \\
\hline 5 & $\begin{array}{l}\text { No major use of } \\
\text { unconsolidated } \\
\text { aquifer }\end{array}$ & -- & $\begin{array}{l}\text { Chase and Council } \\
\text { Grove aquifer and } \\
\text { other Permian rocks }\end{array}$ & 5 \\
\hline 6 & Alluvial & 15 & Great Plains & 7 \\
\hline 7 & do. & 24 & do. & 10 \\
\hline 8 & High Plains & 17 & & \\
\hline 9 & Alluvial & 10 & & \\
\hline 10 & do. & 11 & & \\
\hline 11 & $\begin{array}{l}\text { High Plains and } \\
\text { alluvial }\end{array}$ & 28 & & \\
\hline 12 & High Plains & 29 & & \\
\hline 13 & $\begin{array}{l}\text { High Plains and } \\
\text { alluvial }\end{array}$ & 6 & & \\
\hline 14 & High Plains & 15 & & \\
\hline
\end{tabular}

are similar to those described by Wood (1976). Collection of samples for organic analysis is done according to procedures in Scalf and others (1981). Techniques used to analyze selected chemical constituents sampled from network wells and associated detection limits, accuracy, and precision information are listed in the table 3 , and all constituents except total organic carbon are analyzed by the Kansas Department of Health and Environment (Topeka). Total organic carbon is analyzed by the U.S. Geological Survey's laboratory in Arvada, Colorado.

\section{Chemical Constituents and Properties to be Monitored}

Because one of the principal reasons that the ground-water-quality monitoring network was established was to evaluate the quality of the State's water supplies and because the Safe Drinking Water Act (1974), recent amendments (1986), and the recently adopted State groundwater protection strategy are aimed at prevention of pollution of the State's water supplies, constituents having established drinking-water standards largely determine the principal chemical constituents to be monitored. All chemical constituents for which water samples currently are collected in the network are presented in table 3. Enforceable State and (or) Federal drinking-water standards for those constituents that have a standard are shown in table 1. It is expected that new chemical compounds and constituents will be added in 












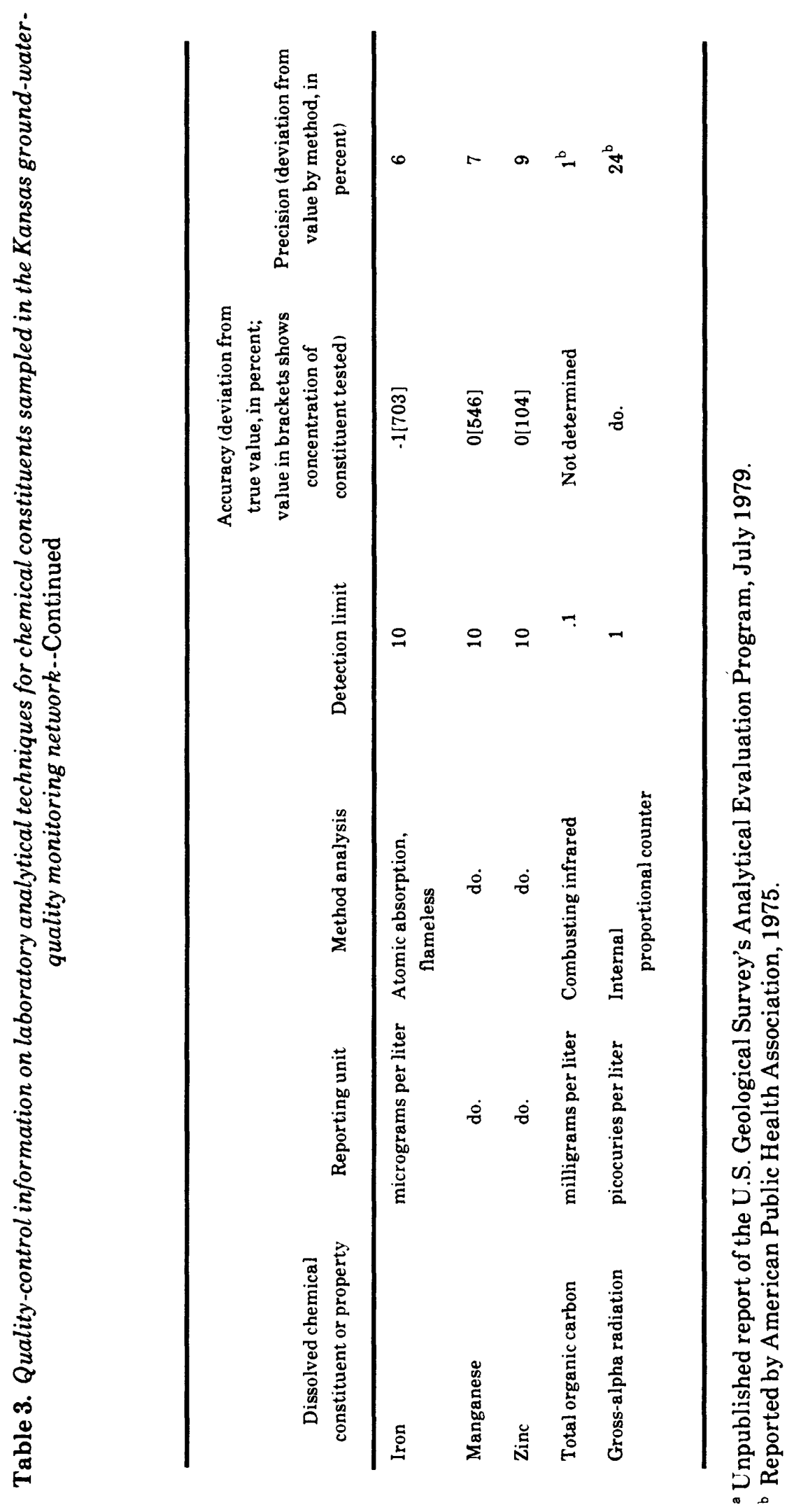


coming years.

In addition to compounds and constituents that have drinking-water or other standards established, major chemical ions in water and physical properties, such as specific conductance, $\mathrm{pH}$, and water temperature, are monitored by the Kansas network. These additional water-quality properties often are associated with certain sources (for example, small pH with mine water) and may provide clues as to the cause of observed changes in concentrations of chemical constituents.

\section{Use of Data to Meet Objectives}

The objectives and intended use of the data collected from the Kansas network for each objective are described in the following paragraphs. The objective is listed first, and then a brief narrative is presented that illustrates how the data can be used and interpreted to meet the stated objective.

(1) Describe regional water-quality characteristics of public- and irrigationwater supplies from principal aquifers in $\mathbf{1 3}$ defined ground-water regions of Kansas.

Data from the Kansas network may be used to estimate regional water-quality characteristics for public and irrigation supplies from the principal aquifers. The mean or median is the statistic that is used to describe a value representative of typical characteristics of a population.

On the basis of data collected from the Kansas ground-water-quality monitoring network, table 4 shows sample size, median, and 95-percent confidence intervals for median concentrations of nitrate, sulfate, and selenium for network wells sampled from 1976-81 in 14 ground-water regions of Kansas. The information in table 4 indicates, with 95-percent confidence, that the true median concentration of each chemical constituent in all water-supply wells sampled in every region during this period was within the range of values indicated. Using nitrate as an example, these data show that typical concentrations of nitrate as nitrogen in water-supply wells sampled in all but one (region 5 , fig. 8) of 14 regions of Kansas were several milligrams per liter less than the $10-\mathrm{mg} / \mathrm{L}$
Maximum Contaminant Level established by the U.S. Environmental Protection Agency (1986a). Thus, in general, median nitrate concentrations in water supplies in the 14 ground-water regions did not exceed the Maximum Contaminant Level.

Sulfate concentrations, in contrast, typically could be larger than the secondary drinking-water Maximum Contaminant Level of $250 \mathrm{mg} / \mathrm{L}$ in ground-water supplies from regions 5,9 , and 13. The upper limits of the 95-percent confidence intervals for these regions were 830 , 680 , and $300 \mathrm{mg} / \mathrm{L}$, respectively (table 4 ). Several reasons could explain the occurrence of large sulfate concentrations. Water supplies in regions 5 and 9 are derived from fractured shale and alluvial deposits containing gypsum as a source for sulfate. In region 13 , irrigation of saline soils containing gypsiferous deposits and infiltration of water from the Arkansas River, which contains large sulfate concentrations, into the alluvial aquifer are likely causes of large sulfate concentrations in ground-water supplies.

As a final example, typical dissolved selenium concentrations as large as 17 or $20 \mu \mathrm{g} / \mathrm{L}$ (micrograms per liter) occur in regions 5 and 13. These concentrations, which are associated with volcanic-ash deposits and occur in shaly sediments, are almost twice the U.S. Environmental Protection Agency's Maximum Contaminant Level of $10 \mu \mathrm{g} / \mathrm{L}$ for this constituent. Selenium is a potentially significant problem in regions 5 and 13.

To determine whether sulfate or selenium is an actual problem, sample sizes in regions 5 , 9 , and 13 would need to be increased to improve estimation of the median sulfate and selenium concentrations. As mentioned, increasing sample size tends to decrease the width of the confidence interval and to increase one's confidence in the estimate. Although the median of a sample in a region yields useful information to the water manager about the typical quality of ground-water supplies, it does not provide information about the percentage of wells that exceed a standard in a region. Other statistics besides the median, such as percentiles or proportions, also can be quite informative. The median reveals much information about typical quality but indicates nothing about the occurrence of outlier concentrations--the very 


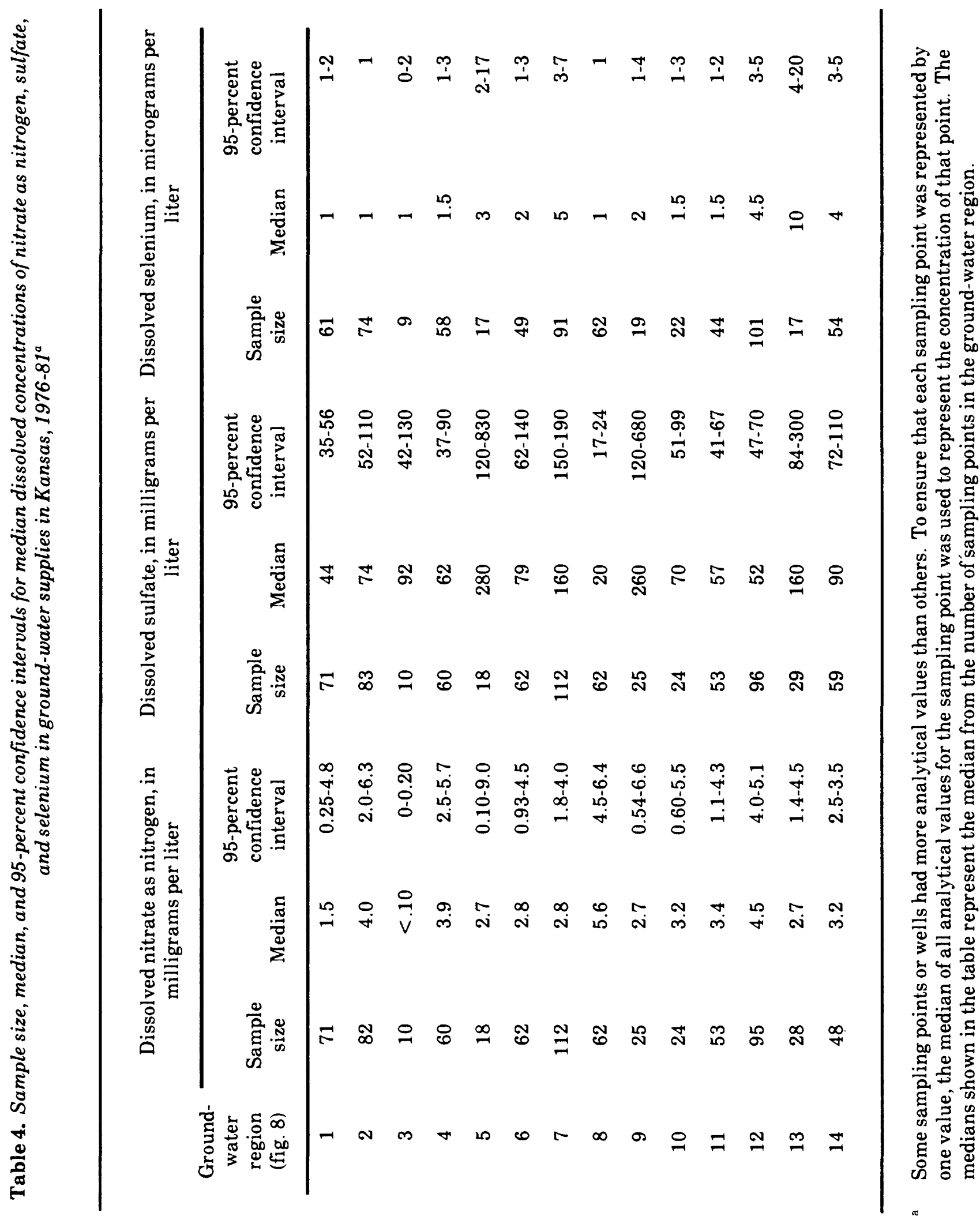


large concentrations.

The percentage of wells that exceed a regulatory standard provides valuable information to management agencies on the severity of the problem. The sample median concentration can be significantly less than a given regulatory standard, indicating, in general, that no problem currently exists. However, a significant proportion (for example, 10 percent or more) of wells could yield water with large concentrations that are greater than a specified standard. This situation is described in the following paragraphs.

Local phenomena can cause large concentrations of particular constituents to occur in water supplies in a region. For example, table 5 shows the 95-percent confidence intervals [computed according to techniques described in Conover (1980)] for the percentage of wells in each region that yielded water with concentrations of nitrate as nitrogen, sulfate, and selenium that exceeded Maximum Contaminant Levels. The upper limit of the 95percent confidence interval for median nitratenitrogen concentrations in region $2(6.3 \mathrm{mg} / \mathrm{L}$, table 4) apparently was not much different than for most other regions. However, the lower limit of the 95-percent confidence interval for the percentage of wells in region 2 that yielded water that exceeded the drinking-water standard was 19 percent (table 5), more than twice as large as the next largest lower limit of the 95-percent confidence interval (9 percent) in region 7 .

The occurrence of a large percentage of wells yielding nitrate-nitrogen concentrations greater than $10 \mathrm{mg} / \mathrm{L}$ probably was due to the fact that almost all wells sampled in region 2 between 1976 and 1981 were shallow-dug domestic wells (a common water-supply source for many rural households in eastern Kansas) that are susceptible to localized surface-derived contamination from feedlots and septic systems. Thus, even though typical nitrate-nitrogen concentrations were not unusual in region 2 , a significant percentage of large concentrations signals a potential problem.

As previously mentioned, all wells were removed from the network in region 2 because the region does not have major significant-yield aquifers that are used extensively and because most public supplies are derived from surface- water sources. Nevertheless, data collected during 1976-81 indicate that significant groundwater quality problems existed in small rural supplies in eastern Kansas. The State of Kansas recently investigated such problems with the implementation of a farmstead well-sampling project (Victor Robbins, Kansas Department of Health and Environment, oral commun., June 1987).

The type of data shown in table 5 can be a simple, but important, quantitative tool with which the water manager can assess the incidence of exceedance of water-quality standards in each region between 1976 and 1981 and whether remedial measures should be implemented. The minimum values in the 95percent confidence intervals shown in table 5 can be interpreted as the minimum percentage of water-supply wells in each region that yielded concentrations during 1976-81 that were larger than the Maximum Contaminant Levels.

Data collected from wells in the monitoring network also may be used to determine how the chemical quality of local ground-water supplies in potential problem areas compare with regional water-quality characteristics. As a simple hypothetical example of this use, if the median nitratenitrogen concentration in water from five supply wells in the vicinity of a fertilizer manufacturer located in region 9 was $8 \mathrm{mg} / \mathrm{L}$, this information could be compared qualitatively with data from table 4 to determine if the nitrate-nitrogen concentrations were apparently larger than the regional median concentration. Because the median from the five wells was $8 \mathrm{mg} / \mathrm{L}$ and is larger than the upper limit of the 95-percent confidence interval in region $9(6.6 \mathrm{mg} / \mathrm{L}$, table $4)$, this would be an indication that some local phenomenon may be causing the larger nitrate concentrations in water supplies near the fertilizer plant. The comparison between the two areas also could be done quantitatively with a two-sample test, such as the Mann-Whitney test (Conover, 1980). The network provides baseline data by which the existence of localized problems can be evaluated quantitatively.

Data from ground-water-quality monitoring networks can be summarized effectively using maps and tables. These types of representation allow water managers to visually discern areas having possible regional water- 
Table 5. Ninety-five percent confidence intervals for percentages of supply wells with water having dissolved concentrations exceeding drinking-water standards for nitrate as nitrogen, sulfate, and selenium in ground-water supplies in Kansas, 1976-81

[U.S. Environmental Protection Agency (1986a, b) Maximum Contaminant Levels are shown in parentheses]

Percentage of wells with water concentrations exceeding drinkingwater standard

\begin{tabular}{|c|c|c|c|c|}
\hline \multirow[b]{2}{*}{$\begin{array}{l}\text { Ground- } \\
\text { water } \\
\text { region } \\
\text { (fig. 8) }\end{array}$} & \multirow[b]{2}{*}{$\begin{array}{c}\text { Sample } \\
\text { size }\end{array}$} & \\
\hline & & $\begin{array}{c}\text { Dissolved nitrate as } \\
\text { nitrogen ( } 10 \\
\text { milligrams per liter) }\end{array}$ & $\begin{array}{c}\text { Dissolved sulfate } \\
\text { (250 milligrams per } \\
\text { liter) }\end{array}$ & $\begin{array}{c}\text { Dissolved selenium } \\
\text { (10 micrograms per } \\
\text { liter) }\end{array}$ \\
\hline 1 & 71 & 6- 24 & 2-16 & $0-14$ \\
\hline 2 & 82 & $19-42$ & $11-31$ & $1-12$ \\
\hline 3 & 10 & $0-32$ & $0-46$ & $0-34$ \\
\hline 4 & 60 & 4- 21 & 7- 28 & $0-11$ \\
\hline 5 & 18 & 5- 47 & $31-78$ & $10-57$ \\
\hline 6 & 62 & $7-28$ & 6- 26 & 6- 27 \\
\hline 7 & 112 & 9- 23 & $24-41$ & 21-42 \\
\hline 8 & 62 & 4- 23 & 0.11 & 0.13 \\
\hline 9 & 25 & 6- 41 & $30-72$ & $0-25$ \\
\hline 10 & 24 & $2-28$ & $1-27$ & $1-30$ \\
\hline 11 & 53 & 4- 22 & 0- 14 & 4- 72 \\
\hline 12 & 95 & 2- 12 & $0-7$ & $13-24$ \\
\hline 13 & 28 & 2- 28 & $22-60$ & 26-77 \\
\hline 14 & 48 & 0- 12 & $1-21$ & $8-30$ \\
\hline
\end{tabular}


Table 6. Dissolved nitrate-nitrogen concentrations in Kansas ground-water supplies, 1976-81

\begin{tabular}{|c|c|c|c|c|c|c|}
\hline \multirow[b]{2}{*}{$\begin{array}{l}\text { Ground- } \\
\text { water region } \\
\text { (fig. 8) }\end{array}$} & \multirow[b]{2}{*}{$\begin{array}{c}\text { Number of } \\
\text { samples }\end{array}$} & \multicolumn{4}{|c|}{ Quartile values (milligrams per liter) } & \multirow[b]{2}{*}{$\begin{array}{c}\text { Percent } \\
\text { above } \\
\text { "MCL"a }\end{array}$} \\
\hline & & $1 \mathrm{st}$ & $\begin{array}{c}\text { 2nd } \\
\text { (median) }\end{array}$ & 3 rd & $\begin{array}{l}\text { 4th } \\
\text { (maxi- } \\
\text { mum) }\end{array}$ & \\
\hline 1 & 71 & 0.10 & 1.5 & 7.0 & 89 & 13 \\
\hline 2 & 82 & .70 & 4.0 & 13 & 120 & 30 \\
\hline 3 & 10 & 0 & 0 & 0 & .60 & 0 \\
\hline 4 & 60 & 1.2 & 3.9 & 7.8 & 15 & 11 \\
\hline 5 & 18 & .20 & 2.7 & 10 & 28 & 22 \\
\hline 6 & 62 & .30 & 2.8 & 6.1 & 87 & 14 \\
\hline 7 & 112 & .40 & 2.8 & 6.6 & 56 & 14 \\
\hline 8 & 62 & 3.7 & 5.6 & 8.7 & 29 & 11 \\
\hline 9 & 25 & .60 & 2.7 & 8.0 & 41 & 20 \\
\hline 10 & 24 & .90 & 3.2 & 7.4 & 13 & 8 \\
\hline 11 & 53 & .60 & 3.4 & 5.8 & 26 & 10 \\
\hline 12 & 95 & 3.1 & 4.5 & 6.0 & 32 & 6 \\
\hline 13 & 28 & .30 & 2.7 & 6.7 & 21 & 11 \\
\hline 14 & 48 & .10 & 3.2 & 3.9 & 13 & 2 \\
\hline
\end{tabular}

a "MCL" is the Maximum Contaminant Level established by the U.S. Environmental Protection Agency (1986a).

quality problems. An example of this is shown in table 6 and figure 11 for dissolved nitratenitrogen concentrations in ground-water supplies in Kansas. The data were summarized from data collected between 1976 and 1981 . Table 6 shows statistical summaries by groundwater region. The regional data is depicted on a State map in figure 11. Figure 11A shows median concentrations of dissolved nitratenitrogen in 14 ground-water regions of Kansas. The largest median nitrate concentrations occurred in western Kansas in regions 8 and 12. These concentrations were less than the $10-\mathrm{mg} / \mathrm{L}$ drinking-water standard, but typical (as defined previously) nitrate concentrations in these regions are large relative to other areas of the State. However, regions 2, 5, and 9 (fig. 11B) had the largest percentage of wells that yielded water with nitrate-nitrogen concentrations larger than the drinking-water standard. These three areas have shaly bedrock with relatively thin soils and many shallow-dug wells, suggesting that localized contamination near the wells may account for the large incidence of nitratenitrogen concentrations greater than $10 \mathrm{mg} / \mathrm{L}$. Other examples are presented in Spruill (1983). 



Figure 11. (A) Median dissolved nitrate-nitrogen concentrations in Kansas ground-water supplies, 1976-81, and (B) percentage of concentrations exceeding Maximum Contaminant Level of 10 milligrams per liter (modified from Spruill, 1983). 
Although use of sample statistics in this manner often is useful to depict gross areal patterns, confidence intervals about the estimates, as shown in tables 4 and 5 provide more quantitative information for decision-making purposes.

(2) Detect possible annual changes or long-term trends in water-quality characteristics of public and irrigation supplies from principal aquifers in $\mathbf{1 3}$ defined ground-water regions of Kansas.

Data collected annually, during approximately the same period each year (to minimize possible seasonal variations), can be used to detect possible changes or trends through time. These data can be analyzed with methods of variance analysis, such as the Kruskal-Wallis test (Conover, 1980), to determine if median concentrations are different between years (for example, to determine if a large-scale effect resulted from some climatic phenomenon, such as an extremely dry year) or by correlation to determine if significant trends exist through periods of several years or more.

Early detection of trends in water quality can be used by the water manager as a basis for implementing remedial measures before a major problem occurs. For example, supply wells developed in glacial-drift aquifers in northeast Kansas (region 1, fig. 8) have been sampled annually since 1977 . A Spearman-rho analysis of annual median nitrate concentrations in water from these wells can be applied to test the one-sided hypothesis that nitrate concentrations in this area are increasing. Basically, the method involves computing a Pearson product moment correlation coefficient on the ranked concentration and time data. The test can be applied to detect increasing trends by testing the hypothesis that larger concentrations are mutually independent from later time increments. A rejection of the null hypothesis at the selected alpha level, as it is referred to (see Iman and Conover, 1983), would be evidence that large concentrations are correlated with later

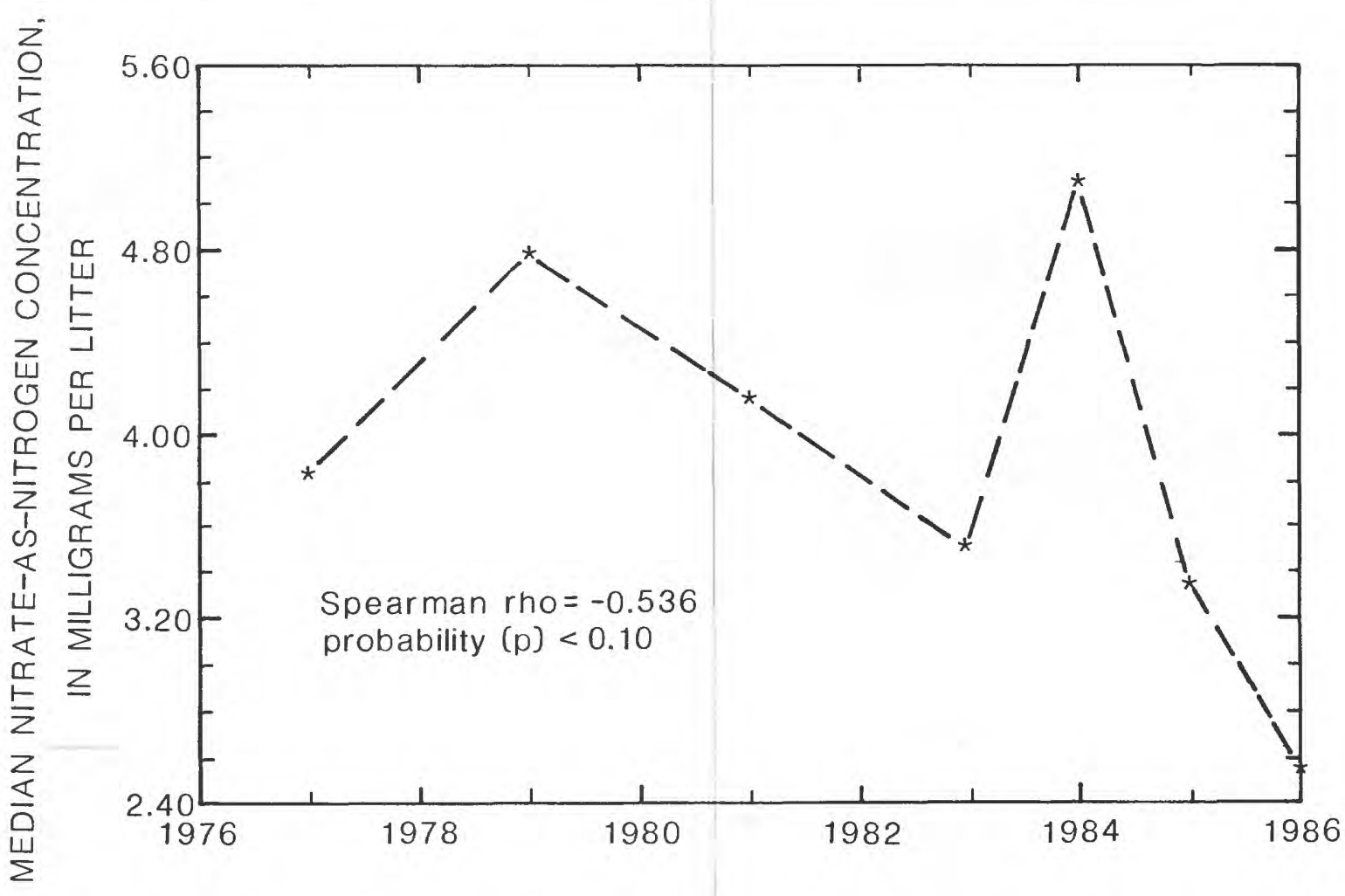

Figure 12. Results of Spearman-rho analysis of trends in nitrate concentrations in water from Kansas network wells developed in glacial-drift aquifers in ground-water region 1, 1977-86. 
time. A complete discussion of the method can be found in Conover (1980).

The Spearman-rho for the 7 years of data was -0.536 (fig. 12), which is smaller than the 0.5357 (Conover, 1980, table A10) required to be a positive trend at alpha $=0.10$. These results suggest that during this 10 -year period, there has been no increase in nitrate concentrations in ground water in northeastern Kansas. In fact, the data indicate a negative trend for this time period. However, if an increase would have occurred for this period, the Kansas Department of Health and Environment would have quantifiable information with which to make a determination as to whether further study of the problem would be appropriate to define the cause of such a large areal trend. Examples of areal displays of the results of trend analysis can be found in Smith and others (1982) and could be done for either individual sampling points or pooled data from all sampling points in a region.

\section{SUMMARY}

Ground-water-quality monitoring networks generally are established because of concerns about whether water supplies are currently contaminated or may be contaminated in the future. These concerns can be addressed by three questions: (1) "What is typical water quality?" (2) "Does the ground water that is available meet existing water-quality standards?", and (3) "Are there indications that water quality is changing so that it will not meet standards in the future?" Ground-water-quality monitoring networks can provide these answers if they are designed carefully. To provide waterquality information for making decisions about appropriate management actions, a network needs to provide data sufficient to answer the questions posed by the management agency.

The value of data derived from a monitoring network depends upon how closely the sample statistics represent the population statistics. The degree to which the sample statistic represents the population statistic is given by confidence intervals. If the confidence interval about an statistical estimate is large, more sampling may be required to improve definition of potential water-quality problems.
The concept of the confidence interval is very important for effective design of monitoring networks because it allows quantitative evaluation of how representative statistics from a given sample are and adjustment of sample sizes accordingly to meet stated objectives.

Data from ground-water-quality monitoring networks can provide estimates of known precision of the typical quality of ground water in defined areas. In Kansas, the current (1988) monitoring network consists of about 250 wells and is intended to describe quality characteristics of public- and irrigation-water supplies in 13 defined ground-water regions of the State. Areal estimates of the median concentration for each chemical constituent along with 95-percent confidence intervals can be used to determine areas of the State where ground-water supplies commonly yield water that does not meet existing State and Federal drinking-water standards. This, in turn, can be used to identify areas that have widespread water-quality problems resulting from natural or anthropogenic causes. Estimates of the percentages of wells that exceed drinking-water standards also can be used to identify the incidence of localized problems in specific areas of the State.

Regional ground-water-quality data also can be evaluated to detect the presence of time trends in ground-water quality and thus can be used to document improvement or degradation through time. In Kansas, ground-water-quality data are collected annually during the summer (late May to September). These data can be analyzed using methods of variance analysis, such as the Kruskal-Wallis test, to determine if concentrations are different between years, or by correlation analysis to determine if significant trends through a period of several years can be detected.

\section{REFERENCES}

American Public Health Association, 1975, Standard methods for the examination of water and wastewater (14th ed.): American Public Health Association, 1142 p. 
Bevans, H.E., Spruill, T.B., and Kenny, J.F., 1985, Kansas ground-water resources, in U.S. Geological Survey, National water summary 1984--Hydrologic events, selected water-quality trends, and groundwater resources: U.S. Geological Survey Water-Supply Paper 2275, p. 217-222.

Bradley, J.V., 1968, Distribution free statistical tests: Englewood Cliffs, New Jersey, Prentice Hall, Inc., $388 \mathrm{p}$.

Cochran, W.G., 1964, Sampling techniques: New York, John Wiley and Sons, lnc., 413 p.

Conover, W.J., 1980, Practical nonparametric statistics: New York, John Wiley and Sons, Inc., $493 \mathrm{p}$.

Davis, J.C., 1987, Statistics and data analysis in geology: New York, John Wiley and Sons, Inc., $646 \mathrm{p}$.

Davis, S.N., and DeWiest, R.J.M., 1966, Hydrogeology: New York, John Wiley and Sons, Inc., $463 \mathrm{p}$.

Dowd, P.A., 1982, Log-normal kriging, the general case: Mathematical Geology, v. 14 , no. 5, p. 475-499.

Gilbert, R.O., 1987, Statistical methods for environmental pollution monitoring: New York, Van Nostrand Rheinhold Co., 320 p.

Hem, J.D., 1985, Study and interpretation of the chemical characteristics of natural water, 3rd ed.: U.S. Geological Survey WaterSupply Paper 2254, 263 p.

Hirsch, R.M., Slack, J.R., and Smith, R.A., 1982, Techniques of trend analysis for monthly water-quality data: Water Resources Research, v. 18, no. 1, p. 107-121.

Hsueh, Ya-Wen, 1987, An optimal resource allocation model for monitoring ambient ground-water quality: Iowa City, University of lowa, unpublished master's thesis.
Hsueh, Ya-Wen, and Rajagapol, R., 1988, Modeling ground water quality sampling decisions: Ground-Water Monitoring Review, v. 8, no. 4, p. 121-134.

Hult, M.F., 1979, Design of a network for monitoring ground-water quality in Minnesota: U.S. Geological Survey OpenFile Report 79-1164, 44 p.

Iman, R.L., and Conover, W.J., 1983, A modern approach to statistics: New York, John Wiley and Sons, Inc., $497 \mathrm{p}$.

Kammerer, P.A., 1983, An overview of groundwater quality data in Wisconsin: U.S. Geological Survey Water-Resources Investigations Report 83-4239, $58 \mathrm{p}$.

Kansas Department of Health and Environment, 1987 , State of Kansas ground-water protection strategy: Topeka, $58 \mathrm{p}$.

Montgomery, R.H., Loftis, J.C., and Harris, Jane, 1987, Statistical characteristics of groundwater quality variables: Ground Water, v. 25 , no. 2, p. 176-184.

Nelson, J.D., and Ward, R.C., 1981, Statistical considerations and sampling techniques for ground-water quality monitoring: Ground Water, v. 19, no. 6, p. 617-625

O'Hearn, M., and Schock, S.C., 1984, Design of a statewide ground-water monitoring network for Illinois: Champaign, Illinois State Water Survey, ISWS Contract Report 354, 76 p.

Olea, R.A., 1984, Systematic sampling of spatial functions: Kansas Geological Survey Series on Spatial Analysis No. 7, 57 p.

Rajagapol, R., 1987, Large data bases and regional ground-water quality assessments--An lowa case study: Ground Water, v. 26, no. 4, p. 415-426.

Rohlf, F.J., and Sokal, R.R., 1969, Statistical tables: San Francisco, W.H. Freeman and Co., $253 \mathrm{p}$. 
Scalf, M.R., McNabb, J.F., Dunlap, W.J., and Cosby, R.L., 1981, Manual of ground water quality sampling procedures: Worthington, Ohio, National Water Well Association, $93 \mathrm{p}$.

Schoewe, W.H., 1949, The geography of Kansas, part 2--Physical geography: Transactions of the Kansas Academy of Sciences, v. 52, no. 3, p. 261-333.

Smith, R.A., Hirseh, R.M., and Slack, J.R., 1982, A study of trends in total phosphorus measurements at NASQAN stations: U.S. Geological Survey Water-Supply Paper $2190,34 \mathrm{p}$.

Snedecor, G.W., and Cochran, W.G., 1967, Statistical methods: Ames, The lowa State University Press, 593 p.

Spruill, T.B., 1983, Statistical summaries of selected chemical constituents in Kansas ground-water supplies, 1976-81: U.S. Geological Survey Open-File Report 83263,29 p.

Spruill, T.B., and Candela, Lucila, 1990, Two approaches to design of monitoring networks: Ground Water, v. 28, no. 3, p. 430-442.

Spruill, T.B., and Kenny, J.F., 1981, Location of sampling sites and available information on wells sampled in the Kansas groundwater-quality monitoring network, 197680: U.S. Geological Survey Open-File Report 81-925, $49 \mathrm{p}$.

Takasaki, K.J., 1977, Elements needed in design of a ground-water quality monitoring network on the Hawaiian Islands: U.S. Geological Survey Water-Supply Paper 2041,23 p.
Taylor, P.J., 1977, Quantitative methods in geography--An introduction to spatial analysis: Prospect Ileights, Illinois, Waveland Press, Inc., 386 p.

U.S. Environmental Protection Agency, 1984, Ground water protection strategy: U.S. Environmental Protection Agency, Office of Ground-Water Protection, $56 \mathrm{p}$.

1986a, Maximum contaminant levels (subpart B of part 141, National primary drinking-water regulations): U.S. Code of Federal Regulations, Title 40, Parts 100 to 149, revised as of July 1, 1986, p. 524-528.

$1986 \mathrm{~b}$, Secondary maximum contaminant levels (section 143.3 of part 143, National secondary drinking-water regulations): U.S. Code of Federal Regulations, Title 40, Parts 100 to 149 , revised as of July 1 , 1986 , p. $587-590$

1987, National primary drinking water regulations: Federal Register, July 8 , 1987, p. 25690-25717.

Whitehead, R.L., and Parliman, D.J., 1979, A proposed ground-water quality monitoring network for Idaho: U.S. Geological Survey Open-File Report 79 $1477,70 \mathrm{p}$.

Wonnacott, T.H., and Wonnacott, R.J., 1977, Introductory statistics: New York, John Wiley and Sons, Inc., $650 \mathrm{p}$.

Wood, W.W., 1976, Guidelines for collection and field analysis of ground-water samples for selected unstable constituents: U.S. Geological Survey Techniques of WaterResources Investigations, Book 1, Chapter D2, $24 \mathrm{p}$. 


\section{APPENDIX I--CONSTRUCTION OF CONFIDENCE INTERVALS}

Confidence intervals at any desired confidence level can be constructed using nonparametric techniques for a median or any specified quantile and will be correct for any frequency distribution. Conover (1980) has presented a method for constructing confidence intervals about a selected quantile for sample sizes less than or equal to 20 . For sample sizes of more than 20 , the following formula (Conover, 1960) may be used to determine an approximate 95-percent confidence interval about any quantile:

$$
\begin{aligned}
& r=n p+(-1.96)[n p(1-p)]^{0.5}, \\
& s=n p+(1.96)[n p(1-p)]^{0.5},
\end{aligned}
$$

where

$r=$ rank of observation used as the lower limit of 95-percent confidence interval [value of both $r$ and $s$ are usually fractions and should be rounded upward to the next higher integers (Conover, 1980)];

$n=$ sample size;

$p=$ selected quantile (that is, $0.5=$ median, $0.75=$ third quantile, and so forth); and

$s=$ rank of observation used as the upper limit of 95 -percent confidence interval.

Thus, for the sequence of 21 numbers $10,20,30,40, \ldots 2,000$ (table 7 ) the median is 110 (the 11 th or middle value of the sequence). Using equations 1 and 2, the 95-percent confidence interval is:

$$
\begin{aligned}
r & =21(0.5)+(-1.96)[21(0.5)(1-0.5)]^{0.5} \\
& =10.5-4.49 ; \\
& =6.01 \text { or the } 7 \text { th number in the sequence or } 70 \\
s & =21(0.5)+(1.96)[21(0.5)(1-0.5)]^{0.5} \\
& =10.5+4.49 \\
& =14.99 \text { or the } 15 \text { th number in the sequence or } 150 .
\end{aligned}
$$









\section{APPENDIX II--COMPUTATION OF SAMPLE SIZE FOR KNOWN DISTRIBUTIONS}

A. Using the convenient properties of a nearly normal distribution (approximated by a $t$ distribution), a sample size for any desired degree of precision of an estimated mean may be computed according to:

$$
n=\frac{\left(t_{0} 05\right)^{2} s^{2}}{L^{2}} \quad \text { (Snedecor and Cochran, 1967), }
$$

where

$$
\begin{aligned}
& n=\quad \text { sample size needed to estimate a mean with desired precision } L \text { (defined below); } \\
& t_{0.05}=1.96 \\
& s^{2}=\quad \text { the sample variance; and } \\
& L=\quad \text { the desired precision of the estimate (for example, if the population mean }=300 \\
& \text { units and maximum error desired was } 10 \text { percent, then } L=30 \text { units). }
\end{aligned}
$$

B. For populations that are skewed (specifically, those which approximate a log-normal distribution), adequate sample sizes to obtain estimates within a desired degree of precision can be determined by using the following expression presented in Gilbert (1987):

$$
n=\frac{Z^{2} s^{2}}{[\ln (d+1)]^{2}}
$$

where

$$
\begin{aligned}
& n=\text { sample size needed to estimate the mean of the natural log-transformed data; } \\
& Z=\quad \text { the standard normal deviate associated with the desired level of confidence of the } \\
& \text { estimate ( } 1.65 \text { for } 95 \text {-percent confidence); } \\
& s^{2}=\quad \text { variance of log-transformed data; } \\
& d=\text { the relative error of the estimate ( } 0.1 \text { would correspond to } 10 \text {-percent error); and } \\
& l n=\text { natural logarithm. }
\end{aligned}
$$




\section{APPENDIX III--COMPUTATION OF SAMPLE SIZE FOR UNKNOWN DISTRIBUTIONS}

For populations where the distribution is unknown or where an estimate of the median or a particular quantile of known precision is needed, the following technique is described to determine sample size required to achieve an estimate of a desired level of precision. The technique is best applied in situations where the available initial sample size is larger than 50 . This technique can be used effectively when a reduction of sample size of an existing network is required due to reductions in funding levels, personnel, or some other reason. It is particularly useful for estimating sample sizes necessary to estimate quantiles at the upper end of the distribution (for example, the 0.9 quantile or the 90th percentile) with known precision where incidence of concentrations larger than existing standards may be important. The technique is outlined below:

(1) Sample sizes must be reduced progressively from the largest available sample using Monte Carlo methods (see Wonnacott and Wonnacott, 1977, for explanation). If, for example, a sample of 100 is a vailable initially, successively smaller subsample sizes at regular intervals $(90,80,70,60$, and so forth) can be selected. At least 10 subsamples of each selected size should be obtained.

(2) A 95-percent confidence interval about the estimated median or quantile of each of the 10 subsamples of the defined sample size is computed according to techniques shown in equations 1 and 2 in Appendix I. For sample sizes of less than 20 and for estimates of any quantile, appropriate techniques can be found in Conover (1980).

(3) The difference between the selected quantile and the upper and lower limits of the confidence interval is computed for each of the 10 subsamples of the defined sample size.

(4) The maximum difference between the sample quantile and upper or lower limits is divided by the quantile and multiplied by 100 to yield the maximum percentage error of the estimate (MEE). The average of MEE for each subsample of a given sample size then is computed. This error is referred to in this report as the average maximum error of the estimate (AMEE). The AMEE is computed for each sample size.

(5) A regression model is formulated relating the AMEE to sample size.

(6) Select the sample size for estimating the selected quantile with the desired level of precision from the regression model. 


\section{APPENDIX IV--NEYMAN OPTIMAL ALLOCATION METHOD}

After the number of strata to be sampled have been determined, sample sizes may be allocated to describe the stratum population within the available budget. Weights may be assigned to each stratum according to a variety of criteria (see Nelson and Ward, 1981). In ground-water-quality monitoring networks, weights might be assigned according to the relative area to be monitored and the relative importance of ground water in each area. If the cost per sample is approximately the same in all strata, then optimum allocation of samples per stratum $\left(n_{i}\right)$ for a fixed total sample size $(N)$ is given by the Neyman allocation formula (Nelson and Ward, 1981):

$$
n_{i}=N \frac{W_{i} S_{i}}{L} \underset{\substack{L \\ W_{i} S_{i} \\ i=1}}{,}
$$

where

$$
\begin{aligned}
N & =\text { total number of sample points in entire network; } \\
n_{\mathrm{i}} & =\text { number of samples in the stratum; } \\
W_{i} & =\text { weighting factor for stratum; } \\
S_{i} & =\text { sample standard deviation of the population in stratum } i ; \text { and } \\
L & =\text { number of strata. }
\end{aligned}
$$

Unless a specific chemical constituent is monitored, a decision must be made as to which of several should be used in equation 5 for estimating sample size for each stratum. Because dissolved solids is used in Kansas as an indicator of suitability for various uses, dissolved-solids concentrations were selected for estimating optimum sample size for each stratum in equation 5 . Dissolved solids may be a reasonable compromise when general monitoring of many chemical constituents is carried out. The total number of samples, $N$ in equation 5 , generally is limited by budgetary considerations and usually is known.

The optimum number of samples per stratum for describing dissolved-solids concentrations in 14 ground-water regions of Kansas (19 total strata, based on areally limited and extensive unconsolidated and consolidated aquifer categories within each ground-water region) is shown in table 8. The sample standard deviations $(S)$ shown in table 8 were calculated from the available sample (dissolved-solids concentrations from wells in each stratum). Weights $(W)$ for each stratum were assigned, based on relative area (in percentage of total area to be monitored) and the estimated importance of ground water in each area. For example, based on area, region 4 (fig. 8) was assigned a total weight of 0.11 or 11 percent of the total area to be monitored. Both unconsolidated and consolidated aquifers are used in this region, with consolidated aquifers being of primary importance. Therefore, more weight (based on estimated relative use) was assigned to consolidated aquifers in region 4; a weight of 0.03 was assigned to the unconsolidated aquifers, and 0.08 was assigned to the consolidated aquifers. A total sample size of 250 ( $N$ in equation 5 ) was assumed and used in computing sample sizes for each stratum ( $n_{i}$ in equation 5$)$. 
Table 8. Allocation of samples in individual strata for describing dissolved-solids concentrations in 14 ground-water regions of Kansas

[Sample sizes derived from data collected between 1976 and 1981]

\begin{tabular}{|c|c|c|c|c|c|c|c|c|c|c|}
\hline \multirow{3}{*}{$\begin{array}{l}\text { Ground- } \\
\text { water } \\
\text { region } \\
\text { (fig. 8) }\end{array}$} & \multicolumn{10}{|c|}{ Aquifer type } \\
\hline & \multicolumn{5}{|c|}{ Unconsolidated } & \multicolumn{5}{|c|}{ Consolidated } \\
\hline & System $^{a}$ & $S_{i}^{\mathrm{b}}$ & $W_{1}{ }^{c}$ & $S_{1} W_{1}$ & $N^{d}$ & System $^{a}$ & $S_{i}^{\mathrm{b}}$ & $W_{i}^{c}$ & $S_{1} W_{1}$ & $N^{c}$ \\
\hline 1 & $\mathbf{E}$ & 238 & 0.04 & 10 & 16 & $\mathbf{E}$ & $200^{\mathrm{e}}$ & 0.01 & 2 & 3 \\
\hline 2 & $\mathbf{L}$ & 92 & .03 & 4 & 6 & & & & & \\
\hline 3 & .. & -. & -. & -. &.- & $\mathbf{E}$ & 227 & .02 & 5 & 8 \\
\hline 4 & $\mathbf{L}$ & 153 & .03 & 5 & 8 & $\mathbf{E}$ & 117 & .08 & 9 & 16 \\
\hline 5 & $-\cdot$ & -- & .. & -. & -- & $\mathbf{E}$ & 236 & .02 & 5 & 8 \\
\hline 6 & L & 201 & .04 & 8 & 13 & $\mathbf{E}$ & 273 & .02 & 5 & 9 \\
\hline 7 & $\mathbf{L}$ & 152 & .14 & 21 & 36 & $\mathbf{E}$ & 204 & .04 & 8 & 13 \\
\hline 8 & $\mathbf{E}$ & 90 & .10 & 9 & 15 & & & & & \\
\hline 9 & $\mathbf{L}$ & 194 & .03 & 6 & 10 & & & & & \\
\hline 10 & $\mathrm{~L}$ & 296 & .03 & 9 & 15 & & & & & \\
\hline 11 & $\mathbf{E}$ & 147 & .04 & 6 & 10 & & & & & \\
\hline 12 & $\mathbf{E}$ & 92 & .20 & 18 & 30 & & & & & \\
\hline \multirow[t]{2}{*}{13} & $\mathbf{E}$ & 176 & .03 & 5 & 9 & & & & & \\
\hline & $\mathbf{L}$ & $300^{f}$ & .01 & 3 & 5 & & & & & \\
\hline 14 & $\mathbf{E}$ & 153 & .09 & 14 & 23 & & & & & \\
\hline
\end{tabular}

a E indicates areally extensive aquifer. L indicates areally limited aquifer.

$S_{i}=$ sample standard deviation from available sample in stratum $i$.

$W_{i}=$ assigned weight to stratum $i$.

d Sample sizes for each aquifer system in each region were computed based on a total of 250 .

e Maximum standard deviation observed for extensive aquifer systems.

f Maximum standard deviation observed for limited aquifer systems. 